Published in final edited form as:

Bioconjug Chem. 2016 February 17; 27(2): 329-340. doi:10.1021/acs.bioconjchem.5b00369.

\title{
Fluorescent Bisphosphonate and Carboxyphosphonate Probes: A Versatile Imaging Toolkit for Applications in Bone Biology and Biomedicine
}

\author{
Shuting Sun ${ }^{\dagger} \ddagger$, Katarzyna M. Błażewska ${ }^{\dagger} \S$, Anastasia P. Kadina ${ }^{\dagger}$, Boris A. Kashemirov ${ }^{\dagger}$, \\ Xuchen Duan $^{\perp}$, James T. Triffitt ${ }^{\perp}$, James E. Dunford ${ }^{\perp}$, R. Graham G. Russell ${ }^{\perp}$, Frank H. \\ Ebetino $^{\ddagger}$, Anke J. Roelofs ${ }^{\#}$, Fraser P. Coxon\#, Mark W. Lundy ${ }^{\ddagger}$, and Charles E. McKenna ${ }^{\dagger},{ }^{*}$ \\ †Department of Chemistry, University of Southern California, Los Angeles, California 90089, \\ United States ₹BioVinc LLC, 6162 Bristol Parkway, Culver City, California 90230, United States \\ §Faculty of Chemistry, Lodz University of Technology, Zeromskiego 116, 90-924 Lodz, Poland \\ ${ }^{\perp}$ Botnar Research Centre, Nuffield Department of Orthopaedics, Rheumatology and \\ Musculoskeletal Sciences, University of Oxford, Nuffield Orthopaedic Centre, Oxford, OX3 7LD, \\ United Kingdom \#Musculoskeletal Research Programme, Institute of Medical Sciences, University \\ of Aberdeen, Aberdeen, AB25 2ZD, United Kingdom
}

\begin{abstract}
A bone imaging toolkit of 21 fluorescent probes with variable spectroscopic properties, bone mineral binding affinities, and antiprenylation activities has been created, including a novel linking strategy. The linking chemistry allows attachment of a diverse selection of dyes fluorescent in the visible to near-infrared range to any of the three clinically important heterocyclic bisphosphonate bone drugs (risedronate, zoledronate, and minodronate or their analogues). The resultant suite of conjugates offers multiple options to "mix and match" parent drug structure, fluorescence emission wavelength, relative bone affinity, and presence or absence of antiprenylation activity, for bone-related imaging applications.
\end{abstract}

\section{Graphical abstract}

*Corresponding Author. mckenna@usc.edu. Phone: +1(213) 740 7007. Fax: +1(213) 7400930. ASSOCIATED CONTENT

Supporting Information

The Supporting Information is available free of charge on the ACS Publications website at DOI: 10.1021/acs.bioconjchem.5b00369.

detailed experimental procedures and synthesis of 7a1-7f2, analytical data, and spectroscopic characterizations (PDF)

The authors declare the following competing financial interest(s): C. E. McKenna is a founder of BioVinc LLC; S. Sun is Chief Operating Officer/Chief Scientist of BioVinc LLC; F. H. Ebetino is the President of BioVinc LLC; M. W. Lundy is Director of Biology for BioVinc LLC. BioVinc LLC currently offers some of the compounds described herein for sale under a license from the University of Southern California. 


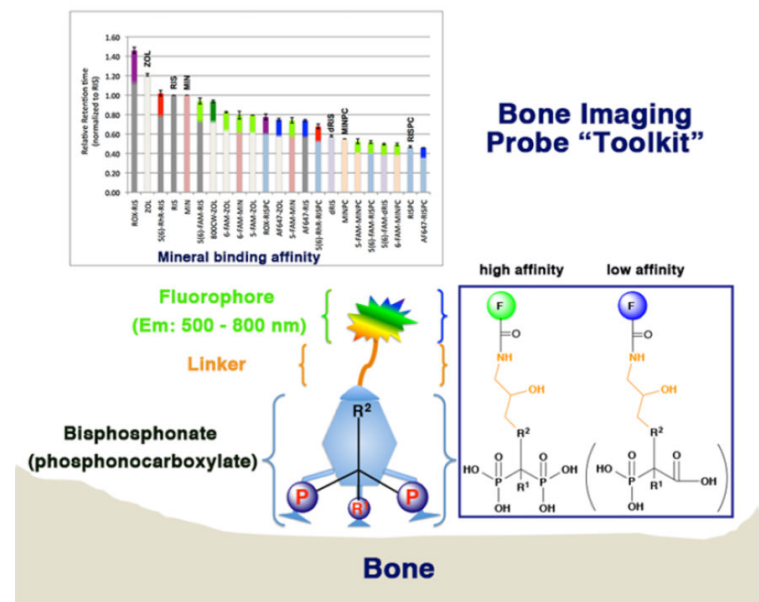

\section{INTRODUCTION}

Methylenebis(phosphonic acid) derivatives, commonly referred to as "bisphosphonates" (BPs), are therapeutic agents for the treatment of bone disorders such as osteoporosis and Paget's disease and are increasingly used in cancer treatment. ${ }^{1,2}$ The more recent generations of clinical bisphosphonate drugs incorporate a basic nitrogen (N-BPs) in a side chain attached to the methylene group. ${ }^{2}$ Farnesyl pyrophosphate synthase (FPPS) in osteoclasts is believed to be the primary intracellular enzymatic target for the antiresorptive activity of N-BPs, but details of N-BP pharmacology, such as skeletal distribution and aspects of cellular uptake, remain to be fully elucidated. ${ }^{2}$ High-dose usage of N-BPs in some cancer patients has been associated with a side effect, known as osteonecrosis of the jaw $(\mathrm{ONJ}) ;{ }^{3,4}$ however, its etiology and mechanism remain unclear. ${ }^{5,6}$ Ongoing questions about how bone structure and function determine response to antiresorptive drugs point to a need for imaging agents able to mimic N-BPs, both with respect to their affinity for bone mineral and their cellular effects.

The $\mathrm{P}-\mathrm{C}-\mathrm{P}$ backbone of BPs mimics the $\mathrm{P}-\mathrm{O}-\mathrm{P}$ backbone of the naturally occurring bone metabolism mediator, inorganic pyrophosphate. BPs generally exhibit strong binding affinity to hydroxyapatite (HAP), the major inorganic material found in bone, and possess exceptional stability against both chemical and biological degradation. The bone-targeting property of BPs suggests an intriguing approach to deliver molecular probes or drugs selectively to bone. ${ }^{7}$ Due to their strong and selective affinity for HAP, BPs labeled with an appropriate imaging agent can be used as molecular indicators for mapping breast cancer microcalcification, calcium urolithiasis, and atherosclerosis. ${ }^{8-11}$

In comparison with radioactive isotope labels, fluorescent probes offer lower potential longterm toxicity. ${ }^{12}$ Visible fluorescent dyes for in vitro imaging offer low cost and compact size. Near-infrared (NIR) dyes with emission wavelengths between 700 and $1000 \mathrm{~nm}$ are attractive for in vivo imaging because tissue autofluorescence is minimized in this optical window. ${ }^{13}$ A refined NIR fluorescence-assisted resection and exploration (FLARE) imaging system was recently introduced and utilized in a first-in-human testing in women undergoing sentinel lymph node mapping for breast cancer. ${ }^{14}$ The successful clinical translation of this 
system may also offer the advantages of NIR imaging for image-guided oncological surgery ${ }^{15}$ and exemplifies the great potential of NIR imaging for monitoring treatment effects in real time. ${ }^{16}$

Three key determinants for the suitability and performance of fluorescent BP probes in a given imaging context are (a) relative and absolute HAP affinity; (b) underlying biological activity (or absence thereof) of the BP moiety; and (c) absorption-emission properties of the conjugated dye. Herein we present the straightforward and adaptable construction of a fluorescent probe toolkit that affords different combinations of these variable properties. The syntheses are described in detail, and all conjugates were fully characterized by ${ }^{1} \mathrm{H},{ }^{31} \mathrm{P}$ NMR, UV-vis, fluorescence emission, high resolution mass spectrometry, and HPLC, as well as relative HAP affinity and antiprenylation activity in a mouse cell assay. The probes were obtained in fair to good yields (50-77\%) and high purity (>98\% pure by NMR and HPLC). A simple linker, epichlorohydrin (6), is introduced that complements our previously described BOC-3-amino propylene oxide linker (5), permitting preparation of a diverse toolkit incorporating all of the heterocyclic BPs in clinical use. Specifically, all three major clinical heterocyclic N-BPs can be linked to any fluorescent dye of interest capable of coupling to an amino or, alternatively, chloromethyl group. Moreover, conjugates that exhibit antiprenylation activity mimicking the parent BP as well as inactive conjugates can be generated. Probes represented in this new "toolkit" have already been applied to studies of BP distribution within bone, ${ }^{17,18}$ to the mechanism of ONJ,${ }^{19-21}$ otosclerosis, ${ }^{22}$ and to the role of macrophages in the extra-skeletal effects of BP on tumor cells. ${ }^{23} \mathrm{~A}$ new example is presented demonstrating differential distribution of high and low bone affinity risedronate (RIS) conjugates in rat bone.

\section{RESULTS AND DISCUSSION}

An early generation N-BP (alendronate) conjugated to Alexa Fluor 488 and carboxyfluorescein was reported previously to lack antiprenylation activity in cells. ${ }^{24,25}$ Several near-IR dye conjugates of pamidronate, ${ }^{8,26} \mathrm{Pam} 78$, Pam800, and commercialized versions (OsteoSense), have also been visualized in vitro and in vivo, but their antiprenylation activity does not appear to have been documented. The synthetic chemistry of the alendronate conjugates suffered from low yields (7-30\%) and the product contained substantial unseparated free alendronate. ${ }^{24,25}$ In general, these conjugates were obtained by reaction with the activated carboxyl form of the fluorescent dye, converting the terminal primary amino group of the N-BP to an amido linkage, thereby deactivating a key pharmacophore in the original N-BP. ${ }^{2}$ Direct acylation by an activated fluorescent label is not readily applicable to the potent heterocyclic N-BP drugs currently used in the clinic, risedronate (RIS, 1a), zoledronate (ZOL, 1d), and minodronate (MIN, 1e), which lack a primary amino group.

We previously introduced a "magic linker" synthesis (Scheme 1, route A) ${ }^{27}$ to prepare the first example of a fluorescently labeled heterocyclic N-BP, formed from RIS (1a), or its phosphonocarboxylate (PC, 1b) and desoxy (dRIS, 1c) analogues, and 5(6)carboxyfluorescein (8). The "magic linker", 3-aminopropene oxide (5, Scheme 1) was socalled due to its surprising chemoselectivity in alkylation of the pyridyl nitrogen in 1a 
relative to the two phosphonate groups, ${ }^{28}$ under mild, semiaqueous, and catalyst-free reaction conditions. ${ }^{27}$ After deprotection of the coupling products $\mathbf{2 a - 2 \mathbf { c }}$, the resulting NBP-linker derivatives $\mathbf{4 a - 4 c}$ advantageously incorporated a primary amine in the linker moiety for facile attachment to the activated ester of an imaging dye, as well as a positively charged pyridinium nitrogen to mimic the protonated nitrogen of the parent drug, ${ }^{29,30}$ and an additional hydroxyl group to counteract decreased aqueous solubility associated with the addition of the hydrophobic alkyl chain. ${ }^{27}$

The nucleophilicity and Lewis basicity of the nitrogen atom in the three major clinical heterocyclic N-BPs $(\mathbf{1 a}, \mathbf{1 d}, \mathbf{1 e})^{30}$ are expected to be major determinants of their conjugation reactivity. Thus, the "magic linker" conditions for RIS required modification for ZOL (1d), $\operatorname{MIN}(\mathbf{1 e})$, and their related analogues (1) $)$. The rank order of $\Delta G_{0}{ }^{\ddagger}$ (defined as the activation free energy of processes with $\Delta G^{0}=0$ ) is imidazoles > pyridines (in acetonitrile), indicating that imidazoles are less nucleophilic than pyridines of comparable basicity. ${ }^{31}$ The protonation status of the heteroatom at different $\mathrm{pH}$ is also critical to reactivity. The $\mathrm{p} K_{\mathrm{a}}$ of the protonated heterocyclic nitrogen of RIS, ZOL, and MIN is 5.67, 6.67, and 6.54, respectively. ${ }^{32}$ In the synthesis of the RIS-linker (2a), the $\mathrm{pH}$ of the reaction mixture was adjusted to 6.0. Under such conditions, more than 50\% ( $71 \%$ calculated) of the RIS nitrogen will be deprotonated, and thus an effective nucleophilie. ${ }^{27}$ However, at $\mathrm{pH} 6.0$, only $18 \%$ of the less nucleophilic ZOL nitrogen (22\% for the MIN nitrogen) is deprotonated, thus the linking reactions were slow (2d) at $\mathrm{pH}$ 6.0. At $\mathrm{pH}$ 7.0-7.5, their reactions were more rapid, but chemoselectivity (N-alkylation vs O-alkylation) was not as good as for RIS and its analogues (1a, 1b, 1c); 10-20\% of side products could be observed (Figure 1A), which were confirmed by HPLC, NMR, and MS to be the products of N,O(P)-dialkylation (Figures S13). The reaction rate of MinPC (1f) coupling to 5 was even slower than that of ZOL under

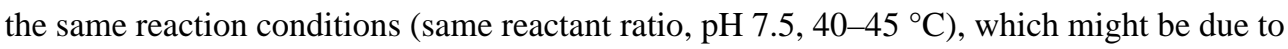
a steric effect from the larger heterocycle; more side product was formed and O-alkylation products were observed in the reaction mixture (Figure S4). With these substrates, the linker had apparently lost some of its magic!

The more reactive epichlorohydrin $\mathbf{6}$ was therefore explored as a new linker precursor. Besides being inexpensive, it is more water-soluble and more reactive than epoxide $\mathbf{5}$, while offering possible subsequent conjugation either directly (with a nucleophilic dye) or indirectly (with an electrophilic dye after conversion to the amine, which proved more practical). Epichlorohydrin was reacted with compounds 1a-1f, yielding intermediates 3a3f, which were ammonolyzed to produce the final drug-linker conjugates $\mathbf{4 a - 4 f}$. The attachment of the linker (Scheme 1, Route B, 1a-1f $\rightarrow$ 3a-3f) proceeded at a higher rate compared to the previous route (Scheme 1, Route A, 1a-1f $\rightarrow$ 2a-2f) under the same

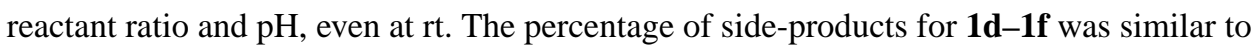
that in Route A; formation of side-products was not observed in the reaction of 1a with 5 equiv of epichlorohydrin (Figure S5). We decided to retain Route A for synthesis of $\mathbf{4 a - 4 c}$, while preferring Route B for synthesis of $\mathbf{4 d - 4 f}$. The reactant ratio of 1:5 (drug:linker (6)) at appropriate $\mathrm{pH}$ (7.4-8.0, depending on the drug) was adopted. In $20 \mathrm{~h}$ at rt, $70-85 \%$ of $\mathbf{4 d -}$ $\mathbf{4 f}$ was obtained. Pure $\mathbf{4 d - 4 f}$ for conjugation with activated fluorescent dyes in the following step were obtained by preparative anion exchange HPLC (Figure 1B). 
This new alternative route (B) to allow the facile construction of a wider fluorescent bisphosphonate "toolkit" is depicted in Scheme 1. The N-BPs and PCs (1a-1f) were reacted with the appropriate epoxide (5 or 6) via the original (A) or new (B) route, yielding the BPor PC-linker intermediates, respectively, which were then reacted with the activated ester of any of a diverse group of fluorescent dyes (generally, commercially available succinimidyl esters were utilized), to afford the final fluorescent imaging probes.

Our results stand in contrast to those of Demberelnyamba et al., who reported ${ }^{33}$ that reaction of pyridine or imidazole with epichlorohydrin in acetonitrile resulted in nucleophilic attack of the pyridine or imidazole nitrogen to displace chlorine to form an epoxide derivative, instead of opening the epoxide ring, whereas we find that reaction of N-BPs with epichlorohydrin under aqueous conditions exclusively yields the epoxide-opened alkyl chloride product, presumably due to facilitation of the epoxide ring opening by the protic solvent.

We reproduced the result of Demberelnyamba et al., reacting pyridine with epichlorohydrin in acetonitrile to obtain exclusively product $\mathbf{1 5 b}$ (Scheme 2), identified by massspectrometry and ${ }^{1} \mathrm{H}$ NMR (however, the ${ }^{1} \mathrm{H}$ NMR for $\mathbf{1 5 b}$ obtained by us was different from that obtained by these authors; see SI for details).

When we reacted pyridine with epichlorohydrin in water in a 1:1 ratio to mimic the conditions used for RIS-epichlorohydrin conjugation, adjusting the $\mathrm{pH}$ to 6 with methylenebisphosphonic acid, we obtained a mixture of conjugates 15a and 15b (Scheme 2 ), at a reaction ratio of 6:1. A reaction ratio of 1:5 (pyridine:epichlorohydrin), the product ratio fell to $15 \mathbf{a}: \mathbf{1 5} \mathbf{b}=1: 2$, suggesting that the $\mathrm{BP}$ moiety strongly influences the chemoselectivity observed with RIS (Figures S6, S7).

\section{Selection of Fluorescent Dye}

A series of fluorescent dyes with distinguishable emission spectra, including three popular near-infrared dyes available commercially, Alexa Fluor 647 (AF647), Sulfo-Cy5, and IRDye $800 \mathrm{CW}(800 \mathrm{CW})$, were selected to generate the fluorescent BP probe "toolkit". Conjugation was carried out between the drug-linker intermediates $(\mathbf{4 a} \mathbf{a}-\mathbf{4 f})$ and the succinimidyl ester (SE) of the different fluorescent dyes under similar reaction conditions (Scheme 1, step C), with minor modifications to reactant ratio and reaction $\mathrm{pH}$. The reactions proceed quickly and can be conveniently monitored by TLC (100\% $\mathrm{MeOH}$ as eluent). To obtain the pure fluorescent BP probes (7a-7f), chromatographic isolation was generally effective. Except for the carboxyfluorescein (FAM, 8) and Rhodamine X-Red (RhR-X, 9) conjugates, which required preparative TLC (100\% $\mathrm{MeOH}$ as eluent) to remove free dye label from the product mixture, all the fluorescent conjugates could be directly purified by preparative reverse phase HPLC in one pass (SI). All the final fluorescent conjugates were fully characterized by HPLC, UV-vis, and fluorescence emission spectroscopy, and ${ }^{1} \mathrm{H}$ and ${ }^{31} \mathrm{P}$ NMR and highresolution MS (SI). It is noteworthy that the isomeric 5- and 6-carboxyfluorescein (FAM, 8) conjugates can be directly synthesized from their respective pure FAM, SE isomers, or alternatively and less expensively separated from the mixed isomers of the FAM conjugates (Figure S8). ${ }^{27}$ 
The probes prepared in this work fluoresce at widely different optical wavelengths (Table 1), allowing simultaneous detection of individual low and high bone affinity BPs and PCs in cells and tissues. The pharmacologically relevant properties, in particular, the HAP affinity of the probes and their effects on protein prenylation, were investigated to guide probe selection for different applications.

\section{HAP Affinity}

The mineral binding affinity of BPs is predominantly determined by the phosphonate groups, while an a-OH group may further enhance the affinity. ${ }^{1,34}$ This is demonstrated by a binding affinity comparison of RIS (1a), RISPC (in which one phosphonate is replaced by a carboxylate, 1b), and dRIS (in which a-OH is replaced by a $\mathrm{H}, \mathbf{1 c}$ ), for which the affinity rank order is RIS > dRIS > RISPC. ${ }^{35,41}$ To investigate whether the attached fluorophore influences the mineral binding affinity, the retention time of each fluorescent BP conjugate on a HAP column was measured and normalized to the retention time of RIS with the conditions adjusted to discriminate among strongly binding compounds. As shown in Figure 2 , the fluorescent conjugates generally have a similar binding affinity ranking to those of the parent compounds. 5(6)-ROX conjugates display slightly higher affinity than their counterparts, while AF647-RIS exhibits the largest relative decrease of HAP affinity compared to other fluorescent RIS conjugates, although retaining strong absolute binding affinity. The affinity rank order of RIS, dRIS, and RISPC conjugates with the same fluorophore remains the same as RIS > dRIS/RISPC (the difference between the dRIS and RISPC conjugates was not highly significant statistically). Measurement of dissociation constants $\left(K_{\mathrm{d}}\right)$ and maximum capacities of 5(6)-ROX-RIS, 5(6)-ROX-RISPC, AF647-RIS, and AF647-RISPC for HAP by Langmuir adsorption isotherms ${ }^{36}$ are in qualitative accordance with the results from HAP column assays (Figure S9) and in vitro dentinebinding assays. ${ }^{18}$

ZOL is somewhat more strongly retained than RIS or MIN (RIS and MIN have similar retention times) (Figure 2). All the fluorescent ZOL, MIN, and MINPC conjugates have a somewhat decreased affinity compared to their parent BPs/PC. 6-FAM-ZOL had a slightly longer retention time on the HAP column than its 5-isomer, in accord with the results for 6FAM-RIS and 5-FAM-RIS, ${ }^{27}$ while 6-FAM-MIN and 5-FAM-MIN (Figure 2) were similar in affinity. Caboxyfluorescein (the dye component of the FAM-conjugates) in a $0.05 \mathrm{mM}$ solution of Tris buffer ( $\mathrm{pH}$ 7.4) displayed no detectable affinity to HAP beads, ${ }^{37}$ and is not retained on a HAP column under BP binding assay conditions (data not shown).

\section{Conjugate Stability}

Aqueous solutions of the conjugates at $\mathrm{pH} 7$ are stable at $\mathrm{rt}$ for several days and can be stored frozen at $-20{ }^{\circ} \mathrm{C}$ for at least 6 months. When administered in vivo to rats, there was no apparent loss of imaging signal on rat tibia over 7 days, consistent with absence of significant linker cleavage. ${ }^{18}$ In previous work ${ }^{38}$ two fluorescent bisphosphonates, 5(6)FAM-RIS (7a1) and AF647-RIS (7a6) administered intravenously in rats (24 h), exhibited a similar inverse correlation to risedronate (1a), alendronate, pamidronate, zoledronate (1d), minodronate (1e), etidronate, neridronate, clodronate, ibandronate, and NE-10790 (1b) between the amount excreted in the urine and HAP affinity. Furthermore, the amount of 
5(6)-FAM-RIS (7a1) and AF647-RIS (7a6) recovered in the urine as a fraction of the administered dose, determined by MS analysis, was similar to recovery of the parent bisphosphonates. ${ }^{38}$

\section{Biological Activity}

The ability of N-BP drugs to exert their antiprenylation effect in bone is ascribed to their inhibition of enzymes in the mevalonic acid pathway and thereby of protein prenylation within the osteoclast. ${ }^{39,40}$ The detection of unprenylated Rap1A (uRap1A) and cell viability of J774.2 macrophages have been used widely as in vitro screening assays to assess the potential antiresorptive activity of N-BPs and related analogues. ${ }^{27,41,42} \mathrm{PC}$ analogues (RISPC, MINPC) are significantly less active than the N-BPs in cell viability assays; $; 1,42$ thus only fluorescent a-hydroxyl BPs and deoxy-BP (dRIS) conjugates were analyzed (Figure 3).

We previously showed that 6-FAM-RIS inhibited Rap1A prenylation in J774s in vitro with a similar potency to RIS ${ }^{27}$ 5(6)-FAM-RIS also inhibited Rap1A prenylation in osteoclasts in vivo. ${ }^{17}$ Here, we detected unprenylated Rap1A in cell lysates from both 5-FAM-RIS- and 6FAM-RIS-treated J774.2 mouse macrophages (Figure 3A), suggesting both these conjugates retain the ability to affect the mevalonate pathway as previously reported for cultured $\mathbf{J} 774.2$ macrophages and for osteoclasts isolated from 5(6)-FAM-RIS-treated rabbits. ${ }^{17}$ 5(6)-FAMdRIS was also active in this assay, at a potency comparable to its parent BP dRIS (Figure 3B). Both 5-FAM-ZOL and 6-FAM-ZOL retained some Rap1A antiprenylation activity, although they were less potent than ZOL (Figure 3C). Antiresorptive activity was recently confirmed for 5-FAM-ZOL in a rat model in vivo. ${ }^{19}$ 5(6)-ROX-RIS was also active in inhibiting prenylation (Figure 3A). By contrast, cells treated with two near-infrared dye BP conjugates, AF647-RIS and 800CW-ZOL up to $100 \mu \mathrm{M}$ did not show accumulation of unprenylated Rap1A. The results of the cell viability assay are in accordance with the prenylation assay (Figure 3D-F), with the exception that AF647-RIS and 800CW-ZOLtreated J774.2 macrophages exhibit modest decreases in viable cell number at high concentrations $(100,500 \mu \mathrm{M})$, which may be due to a nonspecific effect, e.g., calcium chelation lowering the availability of free ionic calcium in the growth medium. Preliminary results for FAM-MIN (7e1, 7e2) and FAM-MINPC (7f1, 7f2) suggested that these conjugates also possess antiprenylation activity (data not shown). The mechanism for the antiprenylation activity of FAM-RIS and FAM-ZOL has not yet been identified. In a preliminary study, the $\mathrm{IC}_{50}$ value for 5(6)-FAM-RIS in isolated FPPS inhibition assays was found to be in the low micromolar region ( $2.7 \mu \mathrm{M}$ vs $5.7 \mathrm{nM}$ for RIS itself), and 5(6)-FAMRIS was slightly more potent in geranylgeranyl diphosphate synthase (GGDPS) inhibition assay than the parent compound ( $2.6 \mu \mathrm{M}$ vs $10.2 \mu \mathrm{M}$ for RIS itself). ${ }^{44}$ While it is feasible that the linker might be cleaved within the cell environment, releasing active "parent drug", this appears inconsistent with the low to unobservable activity seen when the dye, but not the linker, is changed (Figure 3A). Alternatively, a later stage synthase or transferase in the pathway may be involved. 


\section{Differential Imaging}

We used probes selected from the toolkit on the basis of their HAP binding data to study the differential distribution of bisphosphonates into bone relative to their mineral affinity. ${ }^{18,45}$ These studies demonstrated that the lower affinity compounds diffused more deeply into the bone matrix and showed increased localization around osteocytes. The observed differences correlated closely with mineral affinities of the parent BP/PCs, and have been seen in several animal models. ${ }^{18,45}$ Figure 4 illustrates results for a pair of compounds with relatively small differences in mineral affinity (as shown in Figure 2), observed at 7 days post-injection; 5(6)-RhR-RISPC (7a4, low affinity) clearly penetrates further into the bone matrix at sites of bone formation, compared with the higher mineral affinity compound 5(6)-FAM-RIS (7a1). In a separate study, the probe 5-FAM-ZOL (7d1) was used to show that repeated administration of a bisphosphonate results in less retention of that bisphosphonate in bone than a single large dose. This may have implications for the pathogenesis of osteonecrosis of the jaw and potential therapy. ${ }^{19}$ In another recent study, the specific cell types that can internalize bisphosphonates in vitro and in vivo were identified using fluorescently labeled risedronate and zoledronate. ${ }^{17,46,47}$ AF647-RIS (7a6) has also been used recently to identify microcalcifications in breast tumors that are engulfed by tumor-associated macrophages, which may be responsible for the extra-skeletal effects of bisphosphonates on tumor cells. ${ }^{23}$

\section{CONCLUSIONS}

In summary, a new synthetic method using epichlorohydrin as linker has facilitated expansion of a fluorescent N-BP "toolkit" to include clinically relevant ZOL, MIN, and related analogues, with a wide range of fluorescent dyes, complementing our original BOC-3-aminopropylene oxide linking method for synthesis under mild conditions of fluorescent RIS probes. All the fluorescent probes were prepared in good yields (50-77\%) and high purity. They generally retain substantial affinity for bone mineral, reflecting the different affinities of their parent drugs or derivatives. The conjugated fluorophores exert some influence (typically a small reduction, but in one case enhancement) on the HAP affinity of the probes, which needs to be considered when interpreting data generated with such probes. Conjugates of RIS or ZOL with FAM at 10-100 $\mu \mathrm{M}$ exhibited some antiprenylation activity in cellular assays, but the corresponding conjugates with two NIR dyes (Alexa Fluor 647 and IRDye $800 \mathrm{CW}$ ) were inactive at these concentrations. The mechanism of these effects is currently under investigation. The diverse HAP affinities, cell effects, and spectroscopic properties of the probes make them highly useful and versatile new tools for bone-related imaging studies, thus facilitating the understanding of bone physiology and pharmacology.

\section{EXPERIMENTAL PROCEDURES}

\section{General Remarks}

5(6)-, 5-, and 6-Carboxyfluorescein succinimidyl esters (FAM, SE) were purchased from Sigma-Aldrich or Invitrogen, US. 5(6)-Rhodamine Red-X, SE (5(6)-RhR, SE), 5(6)carboxy-X-Rhodamine, SE (5(6)-ROX, SE), and Alexa Fluor 647, SE (AF647, SE) were purchased from Invitrogen; sulfo-Cy5, SE was purchased from Lumiprobe, and IRDye 
800CW, SE was purchased from LI-COR Biosciences. Compounds 1a-1c were kind gifts from Warner Chilcott Pharmaceuticals (formerly P\&G Pharmaceuticals). Compound 1d (zoledronic acid) was purchased from Molekula, UK. Compound 1e (minodronic acid) was purchased from Shanghai Hengrui International Trading Co. LTD, PRC. Compound 1f (3IPEHPC) was synthesized in our lab according to a published procedure. ${ }^{42}$ All other compounds were purchased from Aldrich or Alfa Aesar. Triethylamine (TEA) was distilled from $\mathrm{KOH} ; \mathrm{CH}_{2} \mathrm{Cl}_{2}$ was distilled from $\mathrm{P}_{2} \mathrm{O}_{5}$; and allylamine was distilled under $\mathrm{N}_{2}$. All other compounds were used as supplied by the manufacturer. Thin layer chromatography (TLC) was performed on Merck Silica Gel $60 \mathrm{~F}_{254}$ plates, and the developed plates were visualized under a UV lamp at $354 \mathrm{~nm}$. HPLC separations were performed on a Rainan Dynamax Model SD-200 system with a Rainan Dynamax absorbance detector Model UVDII. NMR spectra were recorded on either $400 \mathrm{MHz}$ Varian, $500 \mathrm{MHz}$ Varian, $600 \mathrm{MHz}$ Varian, or $500 \mathrm{MHz}$ Bruker spectrometers. UV-vis spectra were recorded on a DU 800 spectrometer, and fluorescence emission spectra were taken on either a Jobin Yvon Horiba FluoroMax-3 fluorimeter equipped with a DataMax Software version 2.20 (Jobin Yvon Inc.), Jobin Yvon Nanolog fluorimeter (Jobin Yvon Inc.), RF-5301PC spectrofluorophotometer (Shimadzu), or PTI QuantaMaster C-60SE spectrometer equipped with a 928 PMT detector. High resolution mass spectra were performed by Dr. Ron New at the UC Riverside High Resolution Mass Spectrometry Facility on a PE Biosystems DE-STR MALDI TOF spectrometer with a WinNT (2000) Data System. Other mass spectra were obtained on a Thermo-Finnigan LCQ DECA XP MAX Ion Trap LC/MS/MS spectrometer operated in ESI mode.

Synthesis of Intermediate $\mathbf{4 a - 4 c - D r u g - l i n k e r ~ i n t e r m e d i a t e s ~} \mathbf{4 a - 4 c}$ via Route A were synthesized according to published procedures, ${ }^{27}$ and for detailed experimental procedures and characterization data, see Supporting Information.

\section{1-(3-Chloro-2-hydroxypropyl)-3-(2-hydroxy-2,2-diphosphonoethyl)pyridin-1-} ium, 3a-1-Hydroxy-1-phosphono-2-pyridin-3-yl-ethyl)phosphonic acid, $\mathbf{1 a}$ (57 mg, 0.2 mmol, 1 equiv), was dissolved in $4 \mathrm{~mL}$ of $\mathrm{D}_{2} \mathrm{O}$ and the $\mathrm{pH}$ was adjusted to 6.0 with $\mathrm{Na}_{2} \mathrm{CO}_{3}$ (s). To this solution was added epichlorohydrin 6 ( $79 \mu \mathrm{L}, 1 \mathrm{mmol}, 5$ equiv). The reaction mixture was stirred at rt. The reaction progress was monitored by ${ }^{31} \mathrm{P}$ and ${ }^{1} \mathrm{H}$ NMR. In $4 \mathrm{~h}$ no more epichlorohydrin remained in the reaction mixture. About $8 \%$ of unreacted starting material and no O-alkylation byproducts were observed by ${ }^{31} \mathrm{P}$ NMR. The solvent was removed in vacuo, and the residue was washed with diethyl ether and methanol, filtered, and dried, then subjected to HPLC purification on an SAX column (Macherey-Nagel $21.4 \mathrm{~mm} \times$ $150 \mathrm{~mm}$ SP15/25 Nucleogel column), flow rate: $9 \mathrm{~mL} / \mathrm{min}, \mathrm{UV}$-vis detection at $260 \mathrm{~nm}$. The product was eluted with $\mathrm{A}: \mathrm{H}_{2} \mathrm{O}, \mathrm{B}: 0.5 \mathrm{M}$ TEAB $\mathrm{pH} 7.5$ using a gradient that was increased from $0 \%$ to $40 \%$ over $10 \mathrm{~min}$, maintained at $40 \%$ from 10 to $20 \mathrm{~min}$, and then increased to $100 \%$ of buffer B from 20 to $25 \mathrm{~min}$. The major peak eluting at $11.5 \mathrm{~min}$ was collected (the retention time has \pm 1.5 min error between different runs), and solvents were evaporated, yielding 3a. ${ }^{1} \mathrm{H}$ NMR (400 MHz, $\left.\mathrm{D}_{2} \mathrm{O}\right) \delta 8.72(\mathrm{~s}, 1 \mathrm{H}), 8.49(\mathrm{~d}, J=6.2 \mathrm{~Hz}, 1 \mathrm{H})$, $8.44(\mathrm{~d}, J=8.0 \mathrm{~Hz}, 1 \mathrm{H}), 7.80(\mathrm{dd}, J=8.0,6.1 \mathrm{~Hz}, 1 \mathrm{H}), 4.74(\mathrm{dd}, J=13.5,2.9 \mathrm{~Hz}, 1 \mathrm{H}), 4.47$ (dd, $J=13.6,9.3 \mathrm{~Hz}, 1 \mathrm{H}), 4.29$ (dtd, $J=9.3,4.7,2.9 \mathrm{~Hz}, 1 \mathrm{H}), 3.77-3.56(\mathrm{~m}, 2 \mathrm{H}), 3.29$ (t, $J$ $=11.6 \mathrm{~Hz}, 2 \mathrm{H})$. 


\section{(3-(3-Amino-2-hydroxypropyl)-1-(2-hydroxy-2,2-diphosphonoethyl)-1H- imidazol-3-ium), 4d-Route A: [1-Hydroxy-2-(1H-imidazol-1-yl)ethane-1,1-}

diyl]bis(phosphonic acid), 1 d (40.0 $\mathrm{mg}, 0.15 \mathrm{mmol}, 1.00$ equiv), was dissolved in $3 \mathrm{~mL}$ water and the $\mathrm{pH}$ adjusted to 7.4 with $\mathrm{Na}_{2} \mathrm{CO}_{3}(\mathrm{~s})$. To this solution was added $51 \mathrm{mg}$ of 5 ( 0.29 mmol, 2 equiv) in minimal $\mathrm{MeOH}$. The reaction mixture was stirred at $50{ }^{\circ} \mathrm{C}$ overnight, and the reaction was monitored by ${ }^{31} \mathrm{P}$ NMR. After $19 \mathrm{~h}, 76 \%$ of $\mathbf{2 d}$ had formed. An additional $10.9 \mathrm{mg}$ ( $0.06 \mathrm{mmol}, 0.42$ equiv) of 5 in $\mathrm{MeOH}$ was added to the reaction mixture. After $41 \mathrm{~h}$, less than $5 \%$ of starting material was left and $81 \%$ of $\mathbf{2 d}$ was obtained with $\sim 15 \%$ of side products. The solvent was removed in vacuo, and the resulting white powder was washed with diethyl ether, filtered, and dried, giving $\mathbf{2 d}$, which was used without further purification. The entire sample of 2d was dissolved in 50:50 water:TFA (v/v). After stirring at $\mathrm{rt}$ for overnight, the Boc group was completely removed to form $\mathbf{4 d}$ $\left({ }^{1} \mathrm{H}\right.$ NMR monitoring). The solvent was removed in vacuo, and the residue was washed with diethyl ether and methanol, filtered, and dried, then subjected to HPLC purification on an SAX column (Macherey-Nagel $21.4 \mathrm{~mm} \times 150 \mathrm{~mm}$ SP15/25 Nucleogel column), flow rate: $9 \mathrm{~mL} / \mathrm{min}, \mathrm{UV}-$ vis detection at $230 \mathrm{~nm}$. The product was eluted with $\mathrm{A}: \mathrm{H}_{2} \mathrm{O}, \mathrm{B}: 0.5 \mathrm{M}$ TEAB pH 7.5 using a gradient that was increased from $0 \%$ to $30 \%$ over 10 min, maintained at $30 \%$ from 10 to $15 \mathrm{~min}$, and then increased to $100 \%$ of buffer B from 15 to $35 \mathrm{~min}$. The major peak eluting at 12-14 min was collected (the retention time has \pm 1.5 min error between different runs), and solvents were evaporated, yielding $\mathbf{4 d}$ for the next reaction step. ${ }^{1} \mathrm{H}$ NMR $\left(\mathrm{D}_{2} \mathrm{O}\right): \delta 8.76(\mathrm{~s}, 1 \mathrm{H}), 7.45(\mathrm{~s}, 1 \mathrm{H}), 7.33(\mathrm{~s}, 1 \mathrm{H}), 4.53(\mathrm{dd}, J=7.4,6.8 \mathrm{~Hz}$, 2H), 4.33 (d, $J=13.3 \mathrm{~Hz}, 1 \mathrm{H}), 4.11-4.07$ (m, 2H), 3.21-3.17 (m, 1H), 2.89 (brd, 1H). ${ }^{31} \mathrm{P}$ NMR ( $\left.\mathrm{D}_{2} \mathrm{O}\right): \delta 14.02(\mathrm{~s}, 2 \mathrm{P})$.

Route B: [1-Hydroxy-2-(1H-imidazol-1-yl)ethane-1,1-diyl]-bis(phosphonic acid), 1 d (50.0 $\mathrm{mg}, 0.18 \mathrm{mmol}, 1.00$ equiv), was dissolved in $4 \mathrm{~mL}$ water and the $\mathrm{pH}$ adjusted to 7.4-7.8 with $\mathrm{Na}_{2} \mathrm{CO}_{3}$ (s). To this solution was added $72.8 \mu \mathrm{L}$ of $6(0.93 \mathrm{mmol}, 5$ equiv). The reaction mixture was stirred at $\mathrm{rt}$ overnight, and the reaction was monitored by ${ }^{31} \mathrm{P} \mathrm{NMR}$. After 19 h, 79\% of 3d was obtained with $\sim 15 \%$ of side products and less than $5 \%$ of starting materials. The reaction mixture was extracted with diethyl ether $(3 \times)$, and the aqueous phase evaporated at low pressure, giving 3d, which was used without further purification. The entire sample of $\mathbf{3 d}$ was dissolved in $2 \mathrm{~mL}$ of $\mathrm{NH}_{3} \cdot \mathrm{H}_{2} \mathrm{O}$. After stirring at $\mathrm{rt}$ for $30 \mathrm{~h}, \mathbf{4 d}$ was obtained (MS confirmation). The solvent was removed in vacuo, and the residue was washed with diethyl ether and methanol, filtered, and dried, then subjected to HPLC purification on an SAX column (Macherey-Nagel $21.4 \mathrm{~mm} \times 150 \mathrm{~mm}$ SP15/25 Nucleogel column), flow rate: $9 \mathrm{~mL} / \mathrm{min}, \mathrm{UV}-$ vis detection at $230 \mathrm{~nm}$. The product was eluted with $\mathrm{A}: \mathrm{H}_{2} \mathrm{O}, \mathrm{B}: 0.5 \mathrm{M}$ TEAB pH 7.5 using a gradient that was increased from $0 \%$ to $30 \%$ over 10 min, maintained at $30 \%$ from 10 to $15 \mathrm{~min}$, and then increased to $100 \%$ of buffer B from 15 to $35 \mathrm{~min}$. The major peak eluting from 13.5-15.0 min was collected (the retention time has \pm 1.5 min error between different runs), and solvents were evaporated, yielding $\mathbf{4 d}$ for the next reaction step. ${ }^{1} \mathrm{H}$ NMR $\left(\mathrm{D}_{2} \mathrm{O}\right): \delta 8.76(\mathrm{~s}, 1 \mathrm{H}), 7.45(\mathrm{~s}, 1 \mathrm{H}), 7.33(\mathrm{~s}, 1 \mathrm{H}), 4.53$ (dd, J= 7.4, $6.8 \mathrm{~Hz}$, $2 \mathrm{H}), 4.33$ (d, $J=13.3 \mathrm{~Hz}, 1 \mathrm{H}), 4.11-4.07$ (m, 2H), 3.21-3.17 (m, 1H), 2.89 (brd, $1 \mathrm{H}) .{ }^{31} \mathrm{P}$ $\operatorname{NMR}\left(\mathrm{D}_{2} \mathrm{O}\right): \delta 13.9(\mathrm{~s})$.

Bioconjug Chem. Author manuscript; available in PMC 2016 November 21. 
(1-(3-Amino-2-hydroxypropyl)-3-(2-hydroxy-2,2-diphosphonoethyl)imidazo[1,2a]pyridin-1-ium, Route B), 4e-(1-Hydroxy-2-imidazo[1,2-a] pyridin-3-yl-1phosphonoethyl)phosphonic acid, 1e (140.4 mg, $0.44 \mathrm{mmol}, 1.00$ equiv), was dissolved in 4 $\mathrm{mL}$ water and the $\mathrm{pH}$ adjusted to 7.4-7.8 with $10 \mathrm{M} \mathrm{NaOH}$. To this solution was added $170.9 \mu \mathrm{L}$ of 6 ( $2.18 \mathrm{mmol}, 5$ equiv). The reaction mixture was stirred at rt overnight, and the reaction was monitored by ${ }^{31} \mathrm{P}$ NMR. After $19 \mathrm{~h}, 70 \%$ of $\mathbf{3 e}$ was obtained with $\sim 15 \%$ of side products and $\sim 15 \%$ of starting material. The reaction mixture was extracted with diethyl ether (3-5 times), and the aqueous phase evaporated in low pressure, giving $\mathbf{3 e}$, which was used without further purification. The entire sample of $\mathbf{3 e}$ was dissolved in $8 \mathrm{~mL}$ of $\mathrm{NH}_{3} \cdot \mathrm{H}_{2} \mathrm{O}$. After stirring at RT for $44 \mathrm{~h}, \mathbf{4 e}$ was obtained (MS). The solvent was removed in vacuo, and the residue was washed with diethyl ether and methanol, filtered, and dried, then subjected to HPLC purification on an SAX column (Macherey-Nagel $21.4 \mathrm{~mm} \times 150 \mathrm{~mm}$ SP15/25 Nucleogel column), flow rate: $9 \mathrm{~mL} / \mathrm{min}$, UV-vis detection at $280 \mathrm{~nm}$. Sample was eluted with $\mathrm{A}: \mathrm{H}_{2} \mathrm{O}, \mathrm{B}: 0.5 \mathrm{M}$ TEAB $\mathrm{pH} 7.6$ using a gradient that was increased from $0 \%$ to $30 \%$ over $10 \mathrm{~min}$, maintained at $30 \%$ from 10 to $18 \mathrm{~min}$, and then increased to $100 \%$ of buffer B from 18 to $35 \mathrm{~min}$. The major peak eluting from 9.4 to $11.5 \mathrm{~min}$ was collected (the retention time has \pm 1.5 min error between different runs), and solvents were evaporated, yielding $4 \mathbf{e}$ for the next reaction step. ${ }^{1} \mathrm{H}$ NMR $\left(\mathrm{D}_{2} \mathrm{O}\right): \delta 8.77(\mathrm{~d}, J=7.0 \mathrm{~Hz}, 1 \mathrm{H}), 7.87-7.70$ $(\mathrm{m}, 3 \mathrm{H}), 7.32(\mathrm{dt}, J=7.8,4.2 \mathrm{~Hz}, 1 \mathrm{H}), 4.47(\mathrm{~d}, J=13.5 \mathrm{~Hz}, 1 \mathrm{H}), 4.40-4.13(\mathrm{~m}, 2 \mathrm{H}), 3.53(\mathrm{t}$, $J=11.3 \mathrm{~Hz}, 2 \mathrm{H}$ ), 3.29-3.20 (m, 1H), 2.99-2.90 (part. obscured by triethylamine, about 1H). ${ }^{31} \mathrm{P}$ NMR $\left(\mathrm{D}_{2} \mathrm{O}\right): \delta 16.6(\mathrm{~s})$.

\section{(1-(3-Amino-2-hydroxypropyl)-3-(2-carboxy-2-hydroxy-2- phosphonoethyl)imidazo[1,2-a]pyridin-1-ium, 4f-2-Hydroxy-3-imidazo[1,2-} a]pyridin-3-yl-2-phosphonopropionic acid, $\mathbf{1 f}$ (100 $\mathrm{mg}, 0.35 \mathrm{mmol}, 1.00$ equiv), was dissolved in $2.85 \mathrm{~mL}$ water and the $\mathrm{pH}$ adjusted to $7.4-7.8$ with $10 \mathrm{M} \mathrm{NaOH}$. To this solution was added $137 \mu \mathrm{L}$ of $\mathbf{6}(1.75 \mathrm{mmol}, 5$ equiv). The reaction mixture was stirred at $\mathrm{rt}$ overnight, and the reaction was monitored by ${ }^{31} \mathrm{P}$ NMR. After $19 \mathrm{~h}, 61 \%$ of $\mathbf{3 f}$ was obtained with $\sim 24 \%$ of side products and $\sim 15 \%$ of starting material. The reaction mixture was extracted with diethyl ether (3-5 times), and the aqueous phase evaporated in low pressure, giving $\mathbf{3 f}$, which was used without further purification. The entire sample of $\mathbf{3 f}$ was dissolved in $5 \mathrm{~mL}$ of $\mathrm{NH}_{3} \cdot \mathrm{H}_{2} \mathrm{O}$. After stirring at $\mathrm{rt}$ for $44 \mathrm{~h}, \mathbf{4 f}$ was obtained (MS). The solvent was removed in vacuo, and the residue was washed with diethyl ether and methanol, filtered, and dried, then subjected to HPLC purification on an SAX column (MachereyNagel $21.4 \mathrm{~mm} \times 150 \mathrm{~mm} \mathrm{SP15/25} \mathrm{Nucleogel} \mathrm{column),} \mathrm{flow} \mathrm{rate:} 9 \mathrm{~mL} / \mathrm{min}$, UV-vis detection at $280 \mathrm{~nm}$. The product was eluted with $\mathrm{A}: \mathrm{H}_{2} \mathrm{O}, \mathrm{B}: 0.5 \mathrm{M} \mathrm{TEAB} \mathrm{pH} 7.6$ using a gradient that was increased from $0 \%$ to $30 \%$ over $10 \mathrm{~min}$, maintained at $30 \%$ from 10 to 18 min, and then increased to $100 \%$ of buffer B from 18 to $35 \mathrm{~min}$. The major peak eluting from 9.3 to $11.5 \mathrm{~min}$ was collected (the retention time has $\pm 1.5 \mathrm{~min}$ error between different runs), and solvents were evaporated, yielding $\mathbf{4 f}$ for the next reaction step. ${ }^{1} \mathrm{H}$ NMR $\left(\mathrm{D}_{2} \mathrm{O}\right)$ : $\delta 8.64(\mathrm{~d}, J=7.1 \mathrm{~Hz}, 1 \mathrm{H}), 7.91-7.71(\mathrm{~m}, 2 \mathrm{H}), 7.62(\mathrm{~s}, 1 \mathrm{H}), 7.29(\mathrm{ddd}, J=7.0,5.9,2.2 \mathrm{~Hz}$, $1 \mathrm{H}), 4.51-4.39(\mathrm{~m}, 1 \mathrm{H}), 4.35-4.14(\mathrm{~m}, 2 \mathrm{H}), 3.66(\mathrm{dd}, J=15.8,3.6 \mathrm{~Hz}, 1 \mathrm{H}), 3.35$ (dd, $J=$ 15.7, 7.4 Hz, 1H), 3.26-3.15 (m, 1H), 2.98-2.79 (m, 1H). ${ }^{31} \mathrm{P}$ NMR $\left(\mathrm{D}_{2} \mathrm{O}\right): \delta 14.8$. 


\section{General Method for Preparation of Compounds 7a-7f}

The following synthesis and purification steps were performed under minimal lighting. 4a-f (3-5 equiv) was dissolved in $\mathrm{H}_{2} \mathrm{O}$. The $\mathrm{pH}$ was adjusted to 8.3 with solid $\mathrm{Na}_{2} \mathrm{CO}_{3}$. 5(6)FAM, SE (1 equiv), 5(6)-RhR-X, SE (1 equiv), 5(6)-ROX, SE ${ }^{48}$ (1 equiv), AF647, SE (1 equiv, the structure of AF647 was determined by MS and ${ }^{1} \mathrm{H}$ NMR of its corresponding $\mathrm{BP} / \mathrm{PC}$ conjugates, and is different from the proposed structure in the literature ${ }^{49}$ ), sulfoCy5, SE (1 equiv), or IRDye 800CW, SE (1 equiv) was dissolved in anhydrous DMF and combined with the water solution. The $\mathrm{pH}$ was readjusted to 8.2-8.5 with $\mathrm{Na}_{2} \mathrm{CO}_{3}$, dissolving any precipitate, and the reaction mixture stirred for $3 \mathrm{~h}$-overnight under $\mathrm{rt}$ in darkness. Crude FAM and 5(6)-RhR-X conjugates (7a1-7a4, 7b1-7b2, 7c1-7c2, 7d1-7d2, 7e1-7e2, 7f1-7f2) were purified by TLC on plates $20 \times 20 \mathrm{~cm}^{2}$ or $7 \times 20 \mathrm{~cm}^{2}$ (the size of TLC plates chosen depends on the total crude amount) eluted with $100 \% \mathrm{MeOH}$. Crude reaction mixtures of other dye conjugates were not purified by TLC. The phosphonatecontaining compounds remaining at the origin $\left(R_{f}=0\right)$ were extracted with water; the combined aqueous extracts may be treated with Chelex (sodium form) to aid the extraction process. The solution was centrifuged, and then concentrated in vacuo. The resulting solids were then dissolved in water, $20 \% \mathrm{MeOH}$ in $0.1 \mathrm{M}$ triethylammonium acetate buffer (TEAAc, pH 5.0-5.5), or triethylammonium carbonate buffer (TEAC, $\mathrm{pH}$ 7.0-7.8) and filtered through Nanosep 30K Omega filters. The solution was then purified by preparative/ semipreparative reverse-phase HPLC according to the appropriate method. The final amount of conjugates was calculated from the UV-vis absorption spectrum, and the isolated eluate was concentrated in vacuo and lyophilized. The lyophilized solids have a significantly longer storage shelf life than in solution. For detailed experimental procedures and data for each individual compound, see Supporting Information.

\section{UV-vis Absorption and Fluorescence Emission Spectra}

The samples were dissolved in water and diluted with $0.1 \mathrm{M}$ phosphate buffer or $1 \times$ PBS (for 7d5). Approximating that the labeled bisphosphonates have the same extinction coefficient $(\varepsilon)$ as the carboxylic acid of the free fluorescent label, the final concentrations for all labeled products were calculated from UV-vis absorption spectra at $\lambda=493 \mathrm{~nm}(\varepsilon=$ 73,000 $\mathrm{M}^{-1} \mathrm{~cm}^{-1}$ at $\left.\mathrm{pH} 7.2\right)$ for FAM conjugates (7a1-7a3, 7b1, 7c1, 7d1-7d2, 7e1-7e2, 7f1-7f2), $\lambda=567.5 \mathrm{~nm}\left(\varepsilon=114,850 \mathrm{M}^{-1} \mathrm{~cm}^{-1}\right.$ at $\left.\mathrm{pH} 7.5\right)$ for RhR-X conjugates (7a4, 7b2, 7c2), $\lambda=580 \mathrm{~nm}\left(\varepsilon=72,000 \mathrm{M}^{-1} \mathrm{~cm}^{-1}\right.$ at $\left.\mathrm{pH} 8.0\right)$ for ROX conjugates $(\mathbf{7 a 5}, \mathbf{7 b 3}), \lambda=648$ $\mathrm{nm}\left(\varepsilon=240,000 \mathrm{M}^{-1} \mathrm{~cm}^{-1}\right.$ at $\left.\mathrm{pH} 7.2\right)$ for AF647 conjugates $(\mathbf{7 a 6}, \mathbf{7 b 4}, \mathbf{7 d 3}), \lambda=774 \mathrm{~nm}(\varepsilon$ $=240,000 \mathrm{M}^{-1} \mathrm{~cm}^{-1}$ at $\left.\mathrm{pH} 7.4\right)$ for $800 \mathrm{CW}$ conjugates (7d4), $\lambda=644 \mathrm{~nm}\left(\varepsilon=271,000 \mathrm{M}^{-1}\right.$ $\mathrm{cm}^{-1}$ at $\mathrm{pH} 7.4,1 \times \mathrm{PBS}$ ) for Sulfo-Cy5 conjugates $(\mathbf{7 d 5}) .{ }^{50-56}$

Emission spectra for FAM and RhR-X conjugates were recorded using an excitation wavelength of 490 or $520 \mathrm{~nm}$, respectively. Emission spectra for AF647 conjugates and Sulfo-Cy5 conjugates were recorded using an excitation wavelength of $600 \mathrm{~nm}$. Emission spectra of 5(6)-ROX conjugates were recorded using an excitation wavelength of $575 \mathrm{~nm}$. Emission spectra of IRDye CW800 conjugate was recorded using an excitation wavelength of $750 \mathrm{~nm}$. The set up of excitation slit, emission slit, integration time, and increment were determined to get optimal spectra for each compound, respectively, depending on the sample concentration and spectrometer used. 


\section{Hydroxyapatite Column Chromatography Assay}

The fast performance liquid chromatography (FPLC) system consisted of a Waters 650E advanced protein purification system (Millipore Corp., Waters chromatography division, Milford, MA), a 600E system controller, and a 484 tunable absorbance detector for UV absorbance assessment. Ceramic hydroxyapatite [HAP, $\mathrm{Ca}_{10}\left(\mathrm{PO}_{4}\right)_{6}(\mathrm{OH})_{2}$, Macro-Prep Ceramic Hydroxyapatite Type II $20 \mu \mathrm{m} 100$ g, Bio-Rad Laboratories, Inc., Hercules, CA] was equilibrated with $1 \mathrm{mM}$ phosphate buffer $(\mathrm{pH} 6.8)$ and packed in a $0.66 \mathrm{~cm}$ (diameter) $\times$ $6.5 \mathrm{~cm}$ (length) glass column (Omnifit, Biochem valve inc., Cambridge, U.K.), which was attached to the Waters $650 \mathrm{E}$ advanced protein purification system. Each sample was prepared in $1 \mathrm{mM}$ potassium phosphate buffer, and $100 \mu \mathrm{L}$ of $1 \mathrm{mM}(0.1 \mu \mathrm{mol})$ sample was injected into the FPLC system. Subsequently, the compounds were absorbed and subsequently eluted at a flow rate of $2 \mathrm{~mL} / \mathrm{min}$ using a linear concentration gradient of phosphate buffer from 1 to $1000 \mathrm{mM}$ at $\mathrm{pH}$ 6.8. Fractions of each sample were collected in 80 tubes using an automated fraction collector (Gilson, France) and then used for subsequent ultraviolet (SPECTRAmax PLUS 384, Molecular Devices, CA) or fluorescence spectrometry detection (Wallac Victor, 1420 Multilabel Counter, PerkinElmer, USA). Each fraction contained eluate for $0.3 \mathrm{~min}$ intervals. The elution profile for each sample was determined in triplicate for statistical analysis (Prism, GraphPad Software, USA). Using the native BP (RIS, ZOL, and MIN) as a retention time control/comparator, the chromatographic profiles of each fluorescent probe were normalized to its BP counterpart to allow relative comparisons of separations performed at different times. Data are presented as mean retention times normalized to RIS \pm standard deviation (SD). Significant differences between the compounds and RIS were determined by one-way analysis of variance (ANOVA). Significance was assumed at $p<0.0001$.

\section{Inhibition of Protein Prenylation and Cell Viability Assays}

To determine the effect of fluorescent BP probes on protein prenylation, J774.2 mouse macrophages were plated out at $2 \times 10^{5}$ cells $/ \mathrm{mL}$ in 24 -well plates and left to adhere overnight. Cells were then treated with 10 or $100 \mu \mathrm{M}$ of fluorescent analogues of RIS, dRIS, and ZOL, the respective native BP, or vehicle, for $24 \mathrm{~h}$. Cells were lysed in radioimmunoprecipitation buffer, and proteins were separated by sodium dodecyl sulfate polyacrylamide gel electrophoresis and transferred to polyvinyl difluoride membranes by Western blotting. Membranes were then incubated with antibodies to the unprenylated form of Rap1A (uRap1A) and the housekeeping protein $\beta$-actin, which were detected by incubation with fluorescently labeled secondary antibodies and scanning of membranes on a LI-COR Infrared Imager. Results shown are representative of 2 independent experiments.

To determine the effect of fluorescent BP analogues on cell viability, J774.2 mouse macrophages were plated at $2 \times 10^{5}$ cells $/ \mathrm{mL}$ in 96 -well plates and left to adhere overnight. Cells were then treated with 10,100 , or $500 \mu \mathrm{M}$ of fluorescent analogues of RIS, dRIS, and $\mathrm{ZOL}$, the respective native BP, or vehicle, for $48 \mathrm{~h}$. At the end of the incubation period, AlamarBlue reagent was added to each well and incubation continued for a further $3 \mathrm{~h}$. Fluorescence was detected on a plate reader, and expressed as percent of vehicle control. Results are shown as mean $\pm \mathrm{SD}$ of $\geq 2$ independent experiments, performed at least in duplicate. 


\section{Prenyl Synthase Inhibition Assays}

FPPS and GGDPS assays were performed as described in literature. ${ }^{43,57}$ FPPS was assayed at $10 \mathrm{nM}$ with geranyl pyrophosphate as substrate. GGDPS was assayed at $20 \mathrm{nM}$ with farnesyl pyrophosphate as substrate.

\section{Fluorescent-BP Distribution Study in a Rat Model}

Rat studies were performed according to a protocol approved by the Home Office (UK) and in accordance with the Animals (Scientific Procedures) Act 1986 and the Home Office Code of Practice as previously described. ${ }^{18}$ In brief, male Sprague-Dawley rats, 9 weeks old, were subcutaneously injected with a single dose of 5(6)-FAM-RIS $(0.345 \mathrm{mg} / \mathrm{kg})$ and $5(6)-\mathrm{RhR}-$ RISPC $(0.385 \mathrm{mg} / \mathrm{kg})$. Seven days later, animals were sacrificed and tibiae were collected and fixed in $70 \%$ ethanol, before embedding in methyl methacrylate. The localization of the two probes in the tibia was analyzed in transverse histological sections by confocal microscopy (Zeiss LSM510).

\section{Supplementary Material}

Refer to Web version on PubMed Central for supplementary material.

\section{Acknowledgments}

Compounds 1a-1c were gifts from Warner Chilcott Pharmaceuticals (formerly Procter \& Gamble Pharmaceuticals). This work was supported by the University of Southern California and in part by NIH grants 1R01DC009837, 1R21DE023410, 1R43AR067021-01A1, and 1R43DE025524-01. A.J.R. and F.P.C. acknowledge support from Warner Chilcott. J.D. was supported through funding from the Oxford NIHR Biomedical Research Unit.

\section{ABBREVIATIONS}

$\begin{array}{ll}\text { AF647 } & \text { Alexa Fluor } 647 \\ \text { BP } & \text { bisphosphonate } \\ \text { FAM } & \text { carboxyfluorescein } \\ \text { FPP } & \text { farnesyl pyrophosphate } \\ \text { FPPS } & \text { farnesyl pyrophosphate synthase } \\ \text { GGDPS } & \text { geranylgeranyl diphosphate synthase } \\ \text { HAP } & \text { hydroxyapatite } \\ \text { MIN } & \text { minodronate } \\ \text { N-BP } & \text { nitrogen-containing bisphosphonate } \\ \text { PC } & \text { phosphonocarboxylate } \\ \text { RhR } & \text { Rhodamine Red-X } \\ \text { RIS } & \text { risedronate }\end{array}$




$\begin{array}{ll}\text { ROX } & \text { X-Rhodamine } \\ \text { ZOL } & \text { zoledronate }\end{array}$

\section{REFERENCES}

1. Russell RGG, Watts NB, Ebetino FH, Rogers MJ. Mechanisms of action of bisphosphonates: similarities and differences and their potential influence on clinical efficacy. Osteoporosis Int. 2008; 19:733-759.

2. Ebetino F, Hogan A, Sun S, Tsoumpra M, Duan X, Triffitt J, Kwaasi A, Dunford J, Barnett B, Oppermann U, et al. The relationship between the chemistry and biological activity of the bisphosphonates. Bone. 2011; 49:20-33. [PubMed: 21497677]

3. Reid I, Bolland M, Grey A. Is bisphosphonate-associated osteonecrosis of the jaw caused by soft tissue toxicity? Bone. 2007; 41:318-320. [PubMed: 17572168]

4. Siddiqi A, Payne A, Zafar S. Bisphosphonate-induced osteonecrosis of the jaw: a medical enigma? Oral Surg. Oral Med. Oral Pathol. Oral Radiol. Endod. 2009; 108:e1-e8.

5. Reid I. Osteonecrosis of the jaw: who gets it, why? Bone. 2009; 44:4-10. [PubMed: 18948230]

6. Allen M, Burr D. The pathogenesis of bisphosphonate-related osteonecrosis of the jaw: so many hypotheses, so few data. J. Oral Maxillofac Surg. 2009; 67:61-70. [PubMed: 19371816]

7. Zhang S, Gangal G, Uludag H. 'Magic bullets' for bone diseases: progress in rational design of bone-seeking medicinal agents. Chem. Soc. Rev. 2007; 36:507-531. [PubMed: 17325789]

8. Bhushan K, Tanaka E, Frangioni J. Synthesis of conjugatable bisphosphonates for molecular imaging of large animals. Angew. Chem., Int. Ed. 2007; 46:7969-7971.

9. Figueiredo J, Passerotti C, Sponholtz T, Nguyen H, Weissleder R. A novel method of imaging calcium urolithiasis using fluorescence. J. Urol. 2008; 179:1610-1614. [PubMed: 18295253]

10. Jaffer F, Libby P, Weissleder R. Optical and multimodality molecular imaging: insights into atherosclerosis. Arterioscler., Thromb., Vasc. Biol. 2009; 29:1017-1024. [PubMed: 19359659]

11. Subramanian S, Jaffer F, Tawakol A. Optical molecular imaging in atherosclerosis. J. Nucl. Cardiol. 2010; 17:135-144. [PubMed: 20039152]

12. Kubicek V, Lukes I. Bone-seeking probes for optical and magnetic resonance imaging. Future Med. Chem. 2010; 2:521-531. [PubMed: 21426179]

13. Hilderbrand S, Weissleder R. Near-infrared fluorescence: application to in vivo molecular imaging. Curr. Opin. Chem. Biol. 2010; 14:71-79. [PubMed: 19879798]

14. Troyan S, Kianzad V, Gibbs-Strauss S, Gioux S, Matsui A, Oketokoun R, Ngo L, Khamene A, Azar F, Frangioni J. The FLARE intraoperative near-infrared fluorescence imaging system: a firstin-human clinical trial in breast cancer sentinel lymph node mapping. Ann. Surg. Oncol. 2009; 16:2943-2952. [PubMed: 19582506]

15. Gioux S, Choi H, Frangioni J. Image-guided surgery using invisible near-infrared light: fundamentals of clinical translation. Mol. Imaging. 2010; 9:237-255. [PubMed: 20868625]

16. Leblond F, Davis S, Valdes P, Pogue B. Preclinical whole-body fluorescence imaging: Review of instruments, methods and applications. J. Photochem. Photobiol., B. 2010; 98:77-94. [PubMed: 20031443]

17. Roelofs AJ, Coxon FP, Ebetino FH, Lundy MW, Henneman ZJ, Nancollas GH, Sun S, Blazewska KM, Bala JL, Kashemirov BA, et al. Fluorescent risedronate analogues reveal bisphosphonate uptake by bone marrow monocytes and localization around osteocytes in vivo. J. Bone Miner. Res. 2010; 25:606-616. [PubMed: 20422624]

18. Roelofs AJ, Stewart CA, Sun ST, Blazewska KM, Kashemirov BA, McKenna CE, Russell RGG, Rogers MJ, Lundy MW, Ebetino FH, et al. Influence of bone affinity on the skeletal distribution of fluorescently labeled bisphosphonates in vivo. J. Bone Miner. Res. 2012; 27:835-847. [PubMed: 22228189]

19. Hokugo A, Sun S, Park S, McKenna CE, Nishimura I. Equilibrium-dependent bisphosphonate interaction with crystalline bone mineral explains anti-resorptive pharmacokinetics and prevalence of osteonecrosis of the jaw in rats. Bone. 2013; 53:59-68. [PubMed: 23219943] 
20. Cheong S, Sun S, Kang B, Bezouglaia O, Elashoff D, McKenna CE, Aghaloo TL, Tetradis S. Bisphosphonate uptake in areas of tooth extraction or periapical disease. J. Oral Maxillofac. Surg. 2014; 72:2461-2468. [PubMed: 25262401]

21. Bae S, Sun S, Aghaloo T, Oh JE, McKenna CE, Kang MK, Shin KH, Tetradis S, Park NH, Kim RH. Development of oral osteomucosal tissue constructs in vitro and localization of fluorescentlylabeled bisphosphonates to hard and soft tissue. Int. J. Mol. Med. 2014; 34:559-563. [PubMed: 24920042]

22. Kang WS, Sun S, Nguyen K, Kashemirov BA, McKenna CE, Hacking SA, Quesnel AM, Sewell WF, McKenna MJ, Jung DH. Non-ototoxic local delivery of bisphosphonate to the mammalian cochlea. Otol. Neurotol. 2015; 36:953-960. [PubMed: 25996080]

23. Junankar S, Shay G, Jurczyluk J, Ali N, Down J, Pocock N, Parker A, Nguyen A, Sun S, Kashemirov B, et al. Real-time intravital imaging establishes tumor-associated macrophages as the extraskeletal target of bisphosphonate action in cancer. Cancer Discovery. 2015; 5:35-42. [PubMed: 25312016]

24. Thompson K, Rogers M, Coxon F, Crockett J. Cytosolic entry of bisphosphonate drugs requires acidification of vesicles after fluid-phase endocytosis. Mol. Pharmacol. 2006; 69:1624-1632. [PubMed: 16501031]

25. Coxon FP, Thompson K, Roelofs AJ, Ebetino FH, Rogers MJ. Visualizing mineral binding and uptake of bisphosphonate by osteoclasts and non-resorbing cells. Bone. 2008; 42:848-860. [PubMed: 18325866]

26. Zaheer A, Lenkinski R, Mahmood A, Jones A, Cantley L, Frangioni J. In vivo near-infrared fluorescence imaging of osteoblastic activity. Nat. Biotechnol. 2001; 19:1148-1154. [PubMed: 11731784]

27. Kashemirov BA, Bala JL, Chen X, Ebetino FH, Xia Z, Russell RGG, Coxon FP, Roelofs AJ, Rogers MJ, McKenna CE. Fluorescently labeled risedronate and related analogues: "magic linker" synthesis. Bioconjugate Chem. 2008; 19:2308-2310.

28. Chuiko AL, Filonenko LP, Borisevich AN, Lozinskii MO. Synthesis and properties of hydroxyaminoalkyl esters of hydroxyethylidenebisphosphonic acid. Zh. Obshch. Khim. 1993; 63:1070-1074.

29. Martin M, Arnold W, Heath Hr, Urbina J, Oldfield E. Nitrogen-containing bisphosphonates as carbocation transition state analogs for isoprenoid biosynthesis. Biochem. Biophys. Res. Commun. 1999; 263:754-758. [PubMed: 10512752]

30. Hounslow A, Carran J, Brown R, Rejman D, Blackburn G, Watts D. Determination of the microscopic equilibrium dissociation constants for risedronate and its analogues reveals two distinct roles for the nitrogen atom in nitrogen-containing bisphosphonate drugs. J. Med. Chem. 2008; 51:4170-4178. [PubMed: 18590315]

31. Baidya M, Brotzel F, Mayr H. Nucleophilicities and Lewis basicities of imidazoles, benzimidazoles, and benzotriazoles. Org. Biomol. Chem. 2010; 8:1929-1935. [PubMed: 20449500]

32. $\mathrm{p} K_{\mathrm{a}}$ value. Note: $\mathrm{p} K_{\mathrm{a}}$ of ZOL and MIN were calculated by MarvinSketch and the error is \pm 0.5 . The concentration of microspecies was calculated according to the Henderson-Hasselbalch equation.

33. Demberelnyamba D, Yoon SJ, Lee H. New epoxide molten salts: Key intermediates for designing novel ionic liquids. Chem. Lett. 2004; 33:560-561.

34. van Beek ER, Lowik CWGM, Ebetino FH, Papapoulos SE. Binding and antiresorptive properties of heterocycle-containing bisphosphonate analogs: Structure-activity relationships. Bone. 1998; 23:437-442. [PubMed: 9823450]

35. Duan, X. PhD thesis in Medical Sciences Division. University of Oxford; 2010.

36. Russell RGG, Xia Z, Dunford JE, Oppermann U, Kwaasi A, Hulley PA, Kavanagh KL, Triffitt JT, Lundy MW, Phipps RJ, et al. Bisphosphonates - An update on mechanisms of action and how these relate to clinical efficacy. Ann. N. Y. Acad. Sci. 2007; 1117:209-257. [PubMed: 18056045]

37. Kasugai S, Fujisawa R, Waki Y, Miyamoto K, Ohya K. Selective drug delivery system to bone: small peptide (Asp)6 conjugation. J. Bone Miner. Res. 2000; 15:936-943. [PubMed: 10804024]

38. Lundy, M.; Sun, S.; Duan, X.; McKenna, C.; Jeans, G.; Dobson, R.; Quijano, M.; Triffitt, J.; Russell, RG.; Ebetino, F. J. Bone Miner. Res. New Jersey, USA: Wiley-Blackwell; 2014. Skeletal 
retention and urinary excretion of nitrogen-containing bisphosphonates including fluorescentlylabeled bisphosphonates in rats; p. S262-S262.

39. Luckman SP, Coxon FP, Ebetino FH, Russell RG, Rogers MJ. Heterocycle-containing bisphosphonates cause apoptosis and inhibit bone resorption by preventing protein prenylation: evidence from structure-activity relationships in J774 macrophages. J. Bone Miner. Res. 1998; 13:1668-1678. [PubMed: 9797474]

40. Roelofs, AJ.; Ebetino, FH.; Reszka, AA.; Russell, RGG.; Rogers, MJ. Chapter 81 Bisphosphonates: Mechanisms of Action. In: Bilezikian, JP.; Raisz, LG.; Martin, TJ., editors. Principles of Bone Biology. 3rd. San Diego: Academic Press; 2008. p. 1737-1767.

41. Marma MS, Xia ZD, Stewart C, Coxon F, Dunford JE, Baron R, Kashemirov BA, Ebetino FH, Triffitt JT, Russell RGG, et al. Synthesis and biological evaluation of alpha-halogenated bisphosphonate and phosphonocarboxylate analogues of risedronate. J. Med. Chem. 2007; 50:5967-5975. [PubMed: 17975902]

42. McKenna CE, Kashemirov BA, Blazewska KM, Mallard-Favier I, Stewart CA, Rojas J, Lundy MW, Ebetino FH, Baron RA, Dunford JE, et al. Synthesis, chiral high performance liquid chromatographic resolution and enantiospecific activity of a potent new geranylgeranyl transferase inhibitor, 2-hydroxy-3-imidazo-[1,2-a]pyridin-3-yl-2-phosphonopropionic acid. J. Med. Chem. 2010; 53:3454-3464. [PubMed: 20394422]

43. Dunford JE, Kwaasi AA, Rogers MJ, Barnett BL, Ebetino FH, Russell RG, Oppermann U, Kavanagh KL. Structure-activity relationships among the nitrogen containing bisphosphonates in clinical use and other analogues: time-dependent inhibition of human farnesyl pyrophosphate synthase. J. Med. Chem. 2008; 51:2187-2195. [PubMed: 18327899]

44. The prenyl synthase inhibition (FPPS and GGDPS) was assayed as described previously: Dunford JE, et al. J. Med. Chem. 2008; 51:2187-2195. [PubMed: 18327899] Marma MS, et al. J. Med. Chem. 2007; 50:5967-5975. [PubMed: 17975902]

45. Turek J, Ebetino FH, Lundy MW, Sun ST, Kashemirov BA, McKenna CE, Gallant MA, Plotkin LI, Bellido T, Duan XC, et al. Bisphosphonate Binding Affinity Affects Drug Distribution in Both Intracortical and Trabecular Bone of Rabbits. Calcif. Tissue Int. 2012; 90:202-210. [PubMed: 22249525]

46. Vermeer JA, Jansen ID, Marthi M, Coxon FP, McKenna CE, Sun S, de Vries TJ, Everts V. Jaw bone marrow-derived osteoclast precursors internalize more bisphosphonate than long-bone marrow precursors. Bone. 2013; 57:242-251. [PubMed: 23962725]

47. Verhulst A, Sun S, McKenna CE, D'Haese PC. Endocytotic Uptake of Zoledronic Acid by Tubular Cells May Explain Its Renal Effects in Cancer Patients Receiving High Doses of the Compound. PLoS One. 2015; 10:e0121861. [PubMed: 25756736]

48. The commercially available 5(6)-ROX, SE (mixed isomer) includes 5-ROX, SE; 6-ROX, SE; and bisSE in the ratio of 98:1:1 according to the characteristic data provided by Invitrogen; after purification at this step, the minor components were separated and the final products are the 5isomers.

49. White SS, Li HT, Marsh RJ, Piper JD, Leonczek ND, Nicolaou N, Bain AJ, Ying LM, Klenerman D. Characterization of a single molecule DNA switch in free solution. J. Am. Chem. Soc. 2006; 128:11423-11432. [PubMed: 16939265]

50. Kutyavin IV, Lokhov SG, Afonina IA, Dempcy R, Gall AA, Gorn VV, Lukhtanov E, Metcalf M, Mills A, Reed MW, et al. Reduced aggregation and improved specificity of G-rich oligodeoxyribonucleotides containing pyrazolo[3,4-d]pyrimidine guanine bases. Nucleic Acids Res. 2002; 30:4952-4959. [PubMed: 12433999]

51. Mende I, Hoffmann P, Wolf A, Lutterbuse R, Kopp E, Baeuerle PA, de Baey A, Kufer P. Highly efficient antigen targeting to M-DC8(+) dendritic cells via Fc gamma RIII/CD16-specific antibody conjugates. Int. Immunol. 2005; 17:539-547. [PubMed: 15778289]

52. Lefevre C, Kang HC, Haugland RP, Malekzadeh N, Arttamangkul S, Haugland RP. Texas Red-X and rhodamine Red-X, new derivatives of sulforhodamine 101 and lissamine rhodamine B with improved labeling and fluorescence properties. Bioconjugate Chem. 1996; 7:482-489.

53. Maurel D, Kniazeff J, Mathis G, Trinquet E, Pin JP, Ansanay H. Cell surface detection of membrane protein interaction with homogeneous time-resolved fluorescence resonance energy transfer technology. Anal. Biochem. 2004; 329:253-262. [PubMed: 15158484] 
54. Balaz M, Sundberg M, Persson M, Kvassman J, Monsson A. Effects of surface adsorption on catalytic activity of heavy meromyosin studied using a fluorescent ATP analogue. Biochemistry. 2007; 46:7233-7251. [PubMed: 17523677]

55. Li-Cor. IRDye 800CW, SE spectroscopic properties. [accessed in October, 2015] http:// www.licor.com/bio/products/reagents/irdye/800cw/nhs_ester.

56. Lumiprobe. Sulfo-Cy5, SE spectroscopic properties. [accessed in October, 2015] http:// www.lumiprobe.com/p/sulfo-cy5-nhs-ester.

57. Kavanagh KL, Dunford JE, Bunkoczi G, Russell RG, Oppermann U. The crystal structure of human geranylgeranyl pyrophosphate synthase reveals a novel hexameric arrangement and inhibitory product binding. J. Biol. Chem. 2006; 281:22004-22012. [PubMed: 16698791] 
ำำ

A

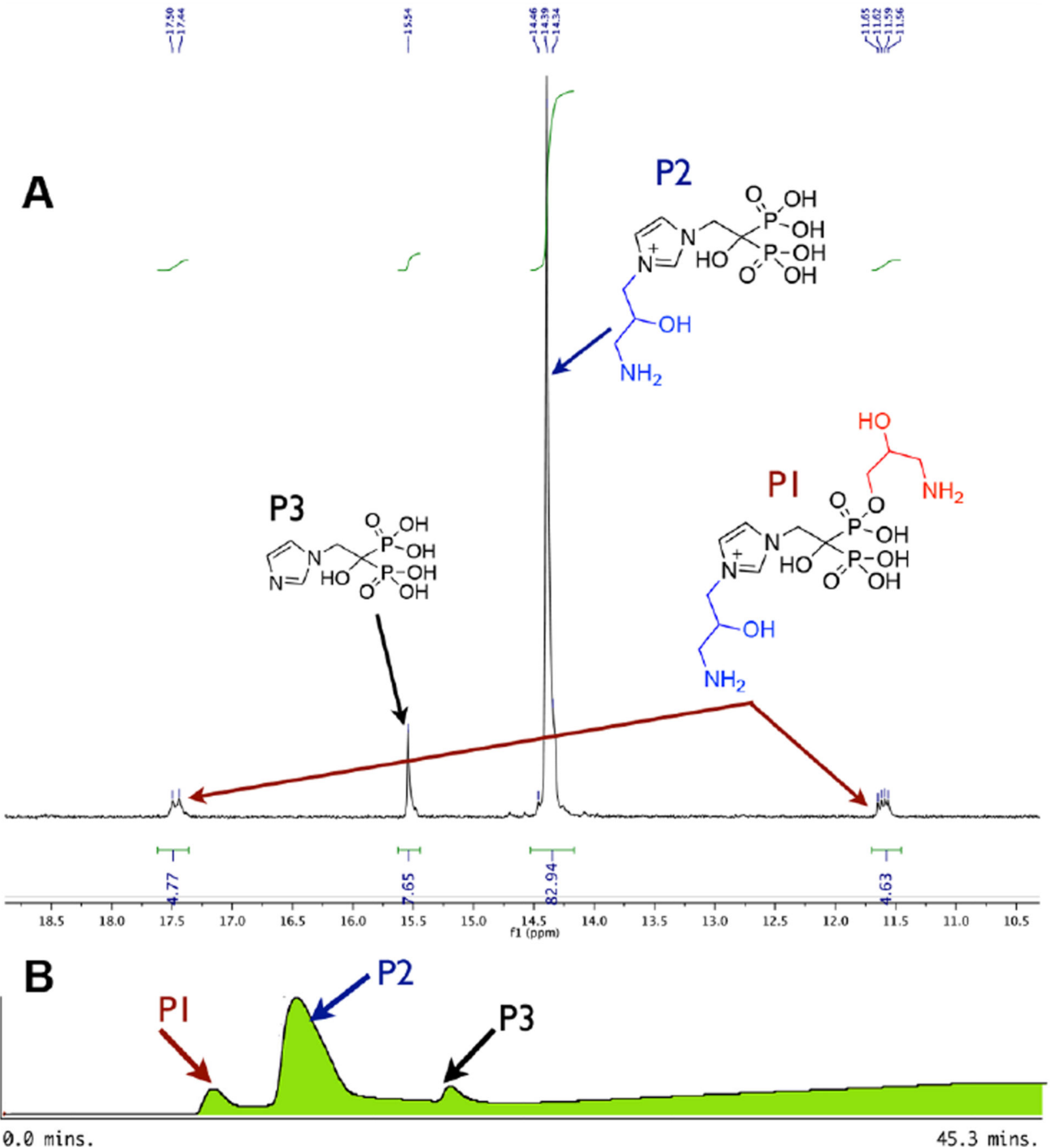

Figure 1.

Reaction of ZOL (1d) and 5. (A) ${ }^{31} \mathrm{P}$ NMR of reaction mixture of $\mathbf{1 d}$ and $\mathbf{5}$ via Route A (in $\mathrm{D}_{2} \mathrm{O}, \mathrm{pH} 7.5 ; 50{ }^{\circ} \mathrm{C}$ for $41 \mathrm{~h}$ then deprotection with TFA: $\left.\mathrm{H}_{2} \mathrm{O}(1: 1)\right)$. (B) HPLC analysis of reaction mixture of ZOL (1d) and $\mathbf{5}$ using a strong anion exchange (SAX) column (Macherey-Nagel $21.4 \mathrm{~mm} \times 150 \mathrm{~mm}$ SP15/25 Nucleogel column), eluted with eluent a, $\mathrm{H}_{2} \mathrm{O}$; b, $0.5 \mathrm{M}$ TEAB pH 7.5, gradient increased from $0 \%$ to $30 \%$ over $10 \mathrm{~min}$, then maintained at $30 \%$ during $10-15 \mathrm{~min}$, then increased to $100 \%$ of eluent b from 15 to $35 \mathrm{~min}$ at $9 \mathrm{~mL} / \mathrm{min}$ flow rate; $\mathrm{UV}-$ vis detection at $230 \mathrm{~nm}$. 


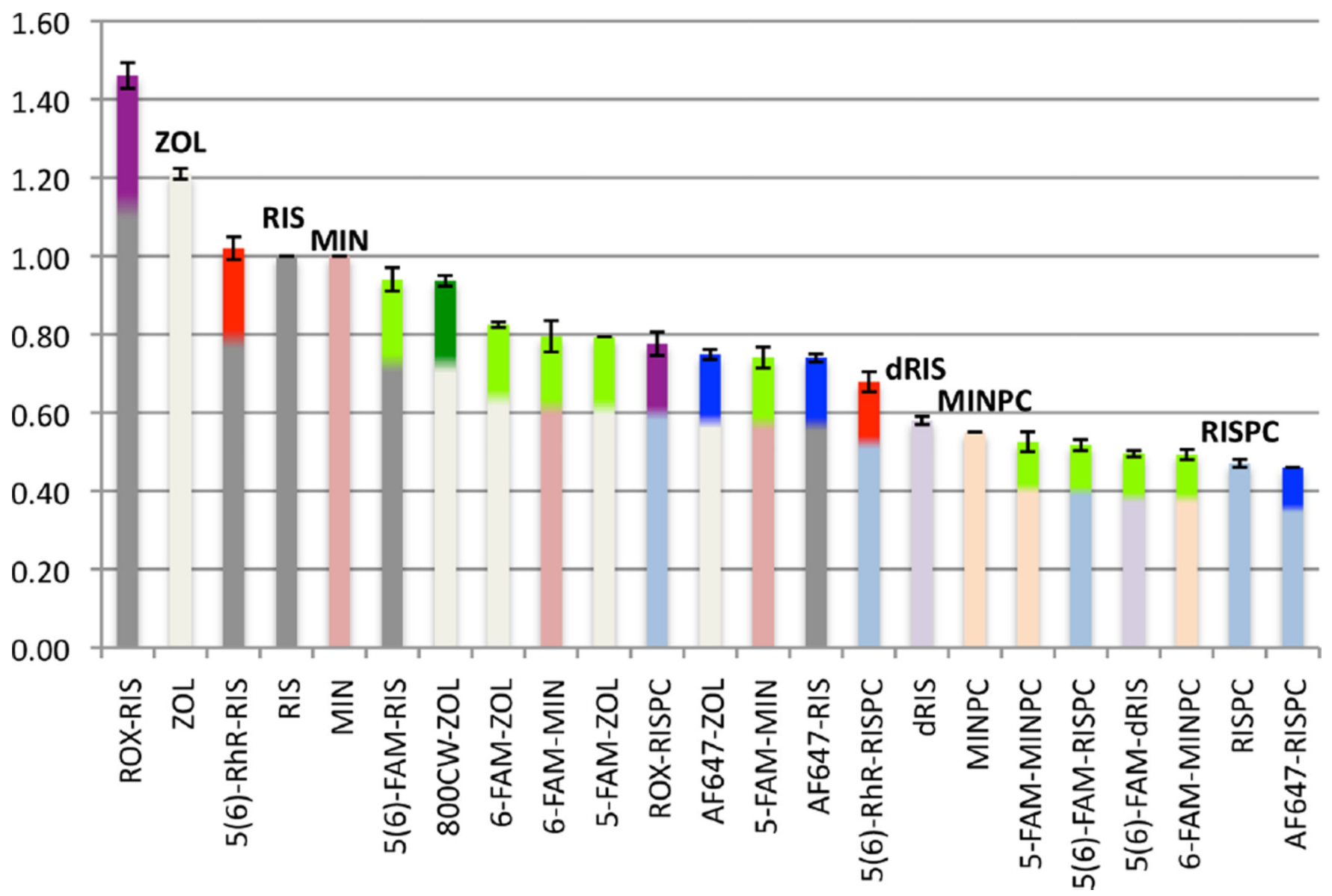

Figure 2.

HAP column binding assay of fluorescent N-BP probes compared to parent N-BP drugs.

Data are shown as mean \pm SD from three individual studies, as relative retention times normalized to RIS $(=1.00)(p<0.0001$, significant differences between the compounds and RIS were determined by one-way analysis of variance (ANOVA)). The color at the top of each data column represents: Green, FAM conjugates; Red, 5(6)-RhR conjugates; Purple, 5(6)-ROX conjugates; Blue, AF647 conjugates; Dark green, 800CW conjugates. 
A

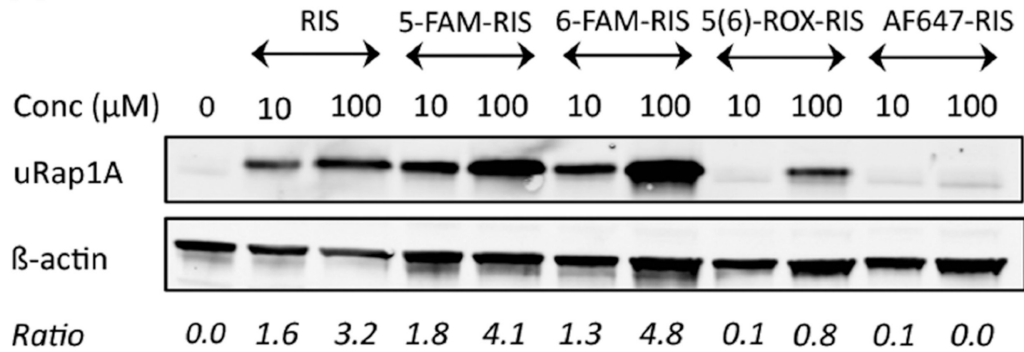

B

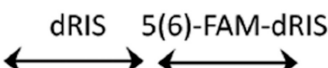

\section{Conc $(\mu \mathrm{M}) \quad 0 \quad 10 \quad 100 \quad 10 \quad 100$}

uRap1A

ß-actin

Ratio

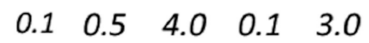

C

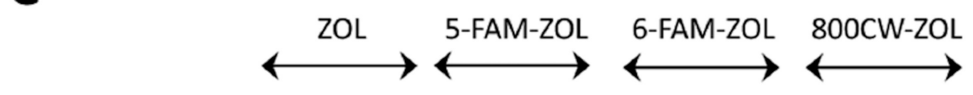

Conc $(\mu \mathrm{M}) \quad 0 \quad 10 \quad 100 \quad 10 \quad 100 \quad 10 \quad 100 \quad 10 \quad 100$

uRap1A

ß-actin

Ratio

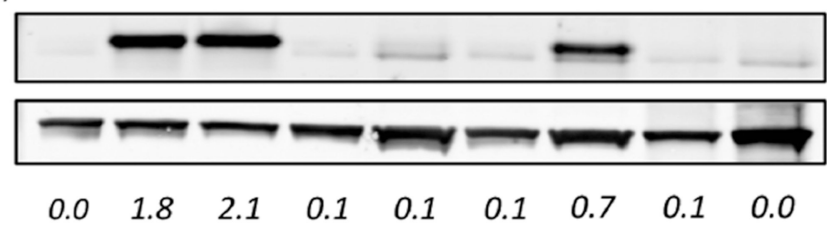

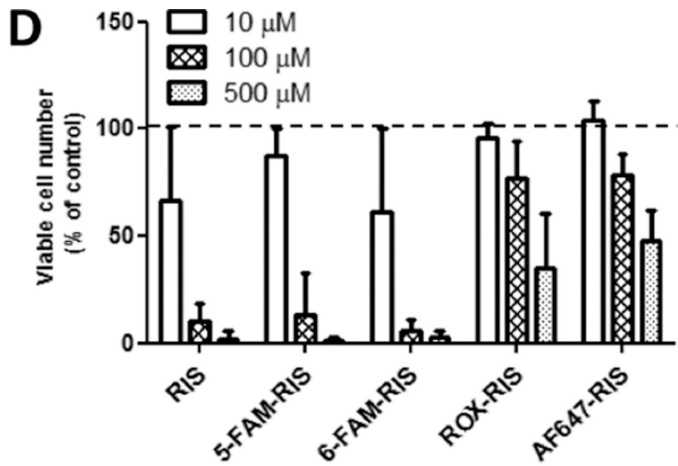
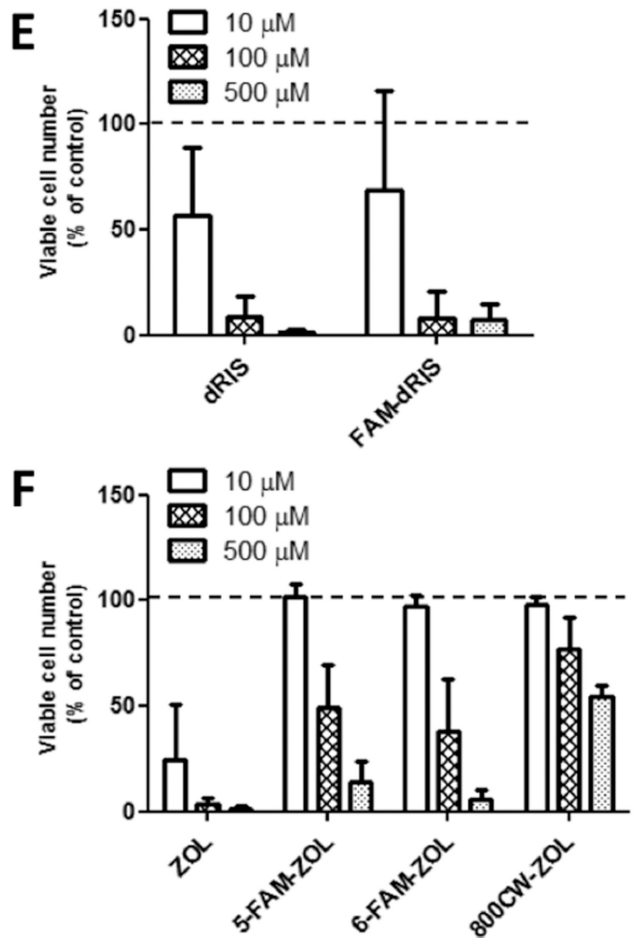

Figure 3.

Prenylation assay and J774.2 cell viability assay of BP fluorescent imaging probes. A-C:

Western blot assays for unprenylated Rap1A (uRap1A). J774.2 macrophages were treated with 10 or $100 \mu \mathrm{M}$ of fluorescent analogues of RIS (A), dRIS (B), and ZOL (C), the respective native $\mathrm{BP}$, or vehicle, for $24 \mathrm{~h}$. Detection of $\beta$-actin served as the loading control. The ratio between abundance of unprenylated Rap1A and $\beta$-actin for each sample is indicated below the blots. D-F: Cell viability assays of J774.2 macrophages. Cells were treated with 10, 100, or $500 \mu \mathrm{M}$ of fluorescent conjugates of RIS (D), dRIS (E), and ZOL (F), the respective native $\mathrm{BP}$, or vehicle, for $48 \mathrm{~h}$. Results are shown as mean $\pm \mathrm{SD}$ of $\geq 2$ independent experiments, performed at least in duplicate. 


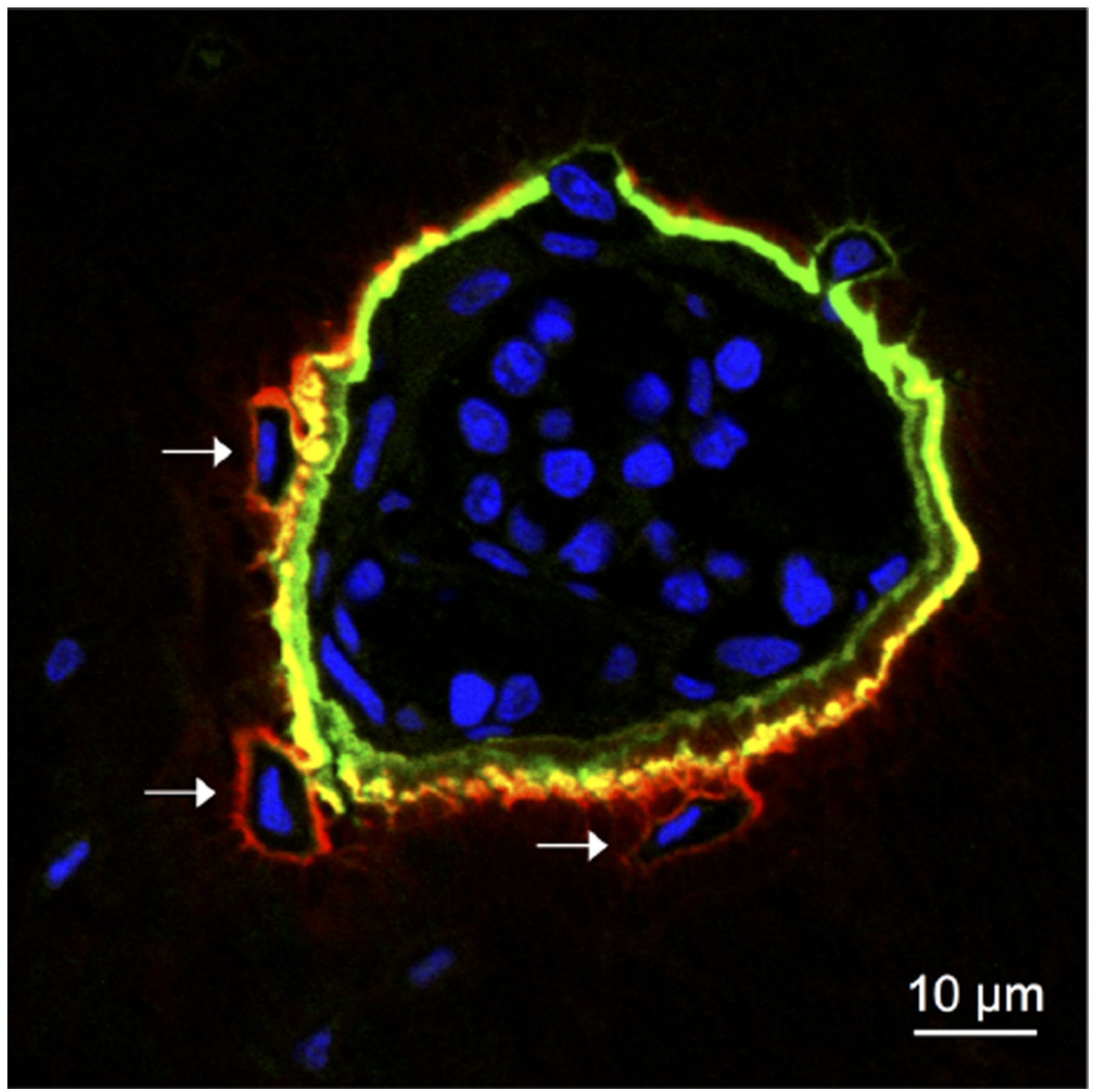

Figure 4.

Localization of a high HAP affinity N-BP drug probe (5(6)-FAM-RIS, green) and a low HAP affinity PC derivative (RhR-RISPC, red) in the bone of a 9-week-old male SpragueDawley rat (0.2 kg). 5(6)-FAM-RIS (0.345 mg/kg) and 5(6)-RhR-RISPC $(0.385 \mathrm{mg} / \mathrm{kg})$ were administered subcutaneously via single dose, and 7 days later their localization pattern was analyzed in transverse histological sections of the tibia. Nuclei were stained with DAPI (blue). Shown is a pocket of bone marrow surrounded by labeled bone matrix, with several newly formed osteocytes indicated by arrows. Note the differential labeling pattern of the 
two compounds with the lower affinity compound (5(6)-RhR-RISPC) penetrating more deeply into the bone matrix and appearing more abundantly in the osteocyte lacunae (arrows). 


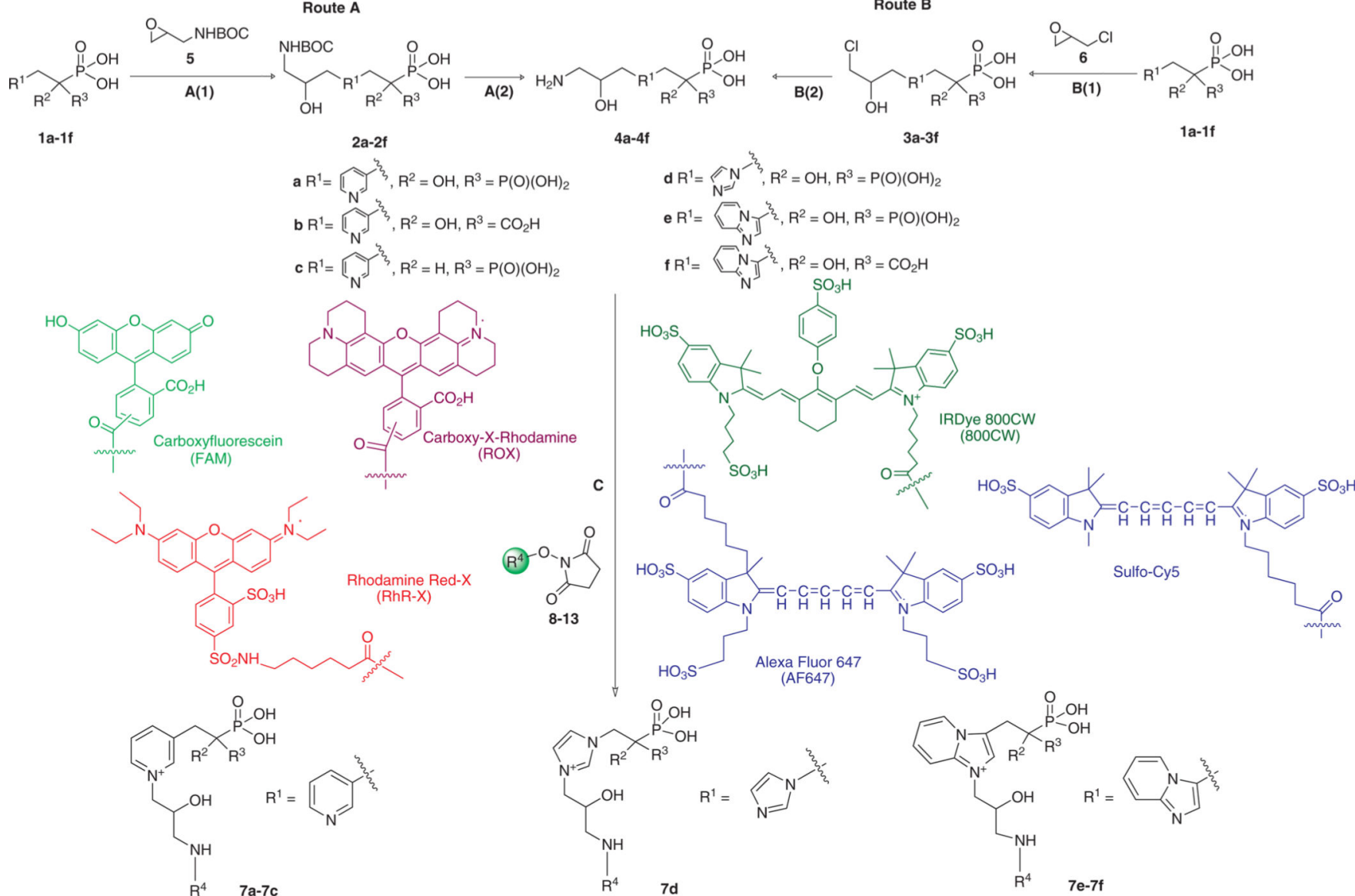

7a1: 5(6)-FAM-RIS. $\mathrm{R}^{2}=\mathrm{OH}, \mathrm{R}^{3}=\mathrm{P}(\mathrm{O})(\mathrm{OH})_{2}, \mathrm{R}^{4}=\mathrm{FAM}$ 7a2: 5-FAM-RIS. $\mathrm{R}^{2}=\mathrm{OH}, \mathrm{R}^{3}=\mathrm{P}(\mathrm{O})(\mathrm{OH})_{2}, \mathrm{R}^{4}=5$-FAM 7a3: 6-FAM-RIS. $\mathrm{R}^{2}=\mathrm{OH}, \mathrm{R}^{3}=\mathrm{P}(\mathrm{O})(\mathrm{OH})_{2}, \mathrm{R}^{4}=6-\mathrm{FAM}$

7a4: 5(6)-RhR-RIS. $\mathrm{R}^{2}=\mathrm{OH}, \mathrm{R}^{3}=\mathrm{P}(\mathrm{O})(\mathrm{OH})_{2}, \mathrm{R}^{4}=\mathrm{RhR}-\mathrm{X}$ 7a5: 5(6)-ROX-RIS. $\mathrm{R}^{2}=\mathrm{OH}, \mathrm{R}^{3}=\mathrm{P}(\mathrm{O})(\mathrm{OH})_{2}, \mathrm{R}^{4}=\mathrm{ROX}$ 7a6: AF647-RIS. $\mathrm{R}^{2}=\mathrm{OH}, \mathrm{R}^{3}=\mathrm{P}(\mathrm{O})(\mathrm{OH})_{2}, \mathrm{R}^{4}=\mathrm{AF} 647$

7b1: 5(6)-FAM-RISPC. $\mathrm{R}^{2}=\mathrm{OH}, \mathrm{R}^{3}=\mathrm{CO}_{2} \mathrm{H}, \mathrm{R}^{4}=\mathrm{FAM}$ 7b2: $5(6)$-RhR-RISPC. $\mathrm{R}^{2}=\mathrm{OH}, \mathrm{R}^{3}=\mathrm{CO}_{2} \mathrm{H}, \mathrm{R}^{4}=\mathrm{RhR}-\mathrm{X}$ 7b3: 5(6)-ROX-RISPC. $\mathrm{R}^{2}=\mathrm{OH}, \mathrm{R}^{3}=\mathrm{CO}_{2} \mathrm{H}, \mathrm{R}^{4}=\mathrm{ROX}$ 7b4: AF647-RISPC. $\mathrm{R}^{2}=\mathrm{OH}, \mathrm{R}^{3}=\mathrm{CO}_{2} \mathrm{H}, \mathrm{R}^{4}=\mathrm{AF} 647$

7c1: 5(6)-FAM-dRIS. $\mathrm{R}^{2}=\mathrm{H}, \mathrm{R}^{3}=\mathrm{P}(\mathrm{O})(\mathrm{OH})_{2}, \mathrm{R}^{4}=\mathrm{FAM}$ 7c2: 5(6)-RhR-dRIS. $\mathrm{R}^{2}=\mathrm{H}, \mathrm{R}^{3}=\mathrm{P}(\mathrm{O})(\mathrm{OH})_{2}, \mathrm{R}^{4}=\mathrm{RhR}-\mathrm{X}$ 7d1: 5-FAM-ZOL. $\mathrm{R}^{2}=\mathrm{OH}, \mathrm{R}^{3}=\mathrm{P}(\mathrm{O})(\mathrm{OH})_{2}, \mathrm{R}^{4}=5$-FAM 7d2: 6-FAM-ZOL. $\mathrm{R}^{2}=\mathrm{OH}, \mathrm{R}^{3}=\mathrm{P}(\mathrm{O})(\mathrm{OH})_{2}, \mathrm{R}^{4}=6$-FAM 7d3: AF647-ZOL. $\mathrm{R}^{2}=\mathrm{OH}, \mathrm{R}^{3}=\mathrm{P}(\mathrm{O})(\mathrm{OH})_{2}, \mathrm{R}^{4}=\mathrm{AF} 647$ 7d4: 800CW-ZOL, $\mathrm{R}^{2}=\mathrm{OH}, \mathrm{R}^{3}=\mathrm{P}(\mathrm{O})(\mathrm{OH})_{2}, \mathrm{R}^{4}=800 \mathrm{CW}$ 7d5: Sulfo-Cy5-ZOL. $\mathrm{R}^{2}=\mathrm{OH}, \mathrm{R}^{3}=\mathrm{P}(\mathrm{O})(\mathrm{OH})_{2}, \mathrm{R}^{4}=$ Sulfo-Cy5

8: Carboxyfluorescein, succimidyl ester (FAM, SE) $R^{4}=F A M$ (representing both 5 - and 6 - isomers) 9: Rhodamine Red $X$, succimidyl ester (RhR-X, SE). $R^{4}=R h R-X$

10: X-rhodamine, succimidyl ester (ROX, SE). $\mathrm{R}^{4}=\mathrm{ROX}$ (representing both 5 - and 6- isomers)

11: Alexa Fluor 647 , succimidyl ester (AF647, SE). $R^{4}=A F 647$

12: IRDye $800 \mathrm{CW}$, succimidyl ester ( $800 \mathrm{CW}, \mathrm{SE}) . \mathrm{R}^{4}=800 \mathrm{CW}$

13: Sulfo-Cy5, succimidyl ester (Sulfo-Cy5, SE). $R^{4}=$ Sulfo-Cy5 7e1: 5-FAM-MIN. $\mathrm{R}^{2}=\mathrm{OH}, \mathrm{R}^{3}=\mathrm{P}(\mathrm{O})(\mathrm{OH})_{2}, \mathrm{R}^{4}=5-\mathrm{FAM}$ 7f1: 5-FAM-MINPC. $\mathrm{R}^{2}=\mathrm{OH}, \mathrm{R}^{3}=\mathrm{CO}_{2} \mathrm{H}, \mathrm{R}^{4}=5$-FAM 7f2: 6-FAM-MINPC. $\mathrm{R}^{2}=\mathrm{OH}, \mathrm{R}^{3}=\mathrm{CO}_{2} \mathrm{H}, \mathrm{R}^{4}=6-\mathrm{FAM}$ 7e2: 6-FAM-MIN. $\mathrm{R}^{2}=\mathrm{OH}, \mathrm{R}^{3}=\mathrm{P}(\mathrm{O})(\mathrm{OH})_{2}, \mathrm{R}^{4}=6-\mathrm{FAM}$

Scheme 1. Synthesis of Fluorescent Bisphosphonate "Toolkit"a

${ }^{a} \mathrm{~A}(1): \sim 5 \% \mathrm{MeOH} / \mathrm{H}_{2} \mathrm{O}, 40-50{ }^{\circ} \mathrm{C} ; \mathrm{A}(2): 1: 1 \mathrm{TFA} / \mathrm{H}_{2} \mathrm{O}, \mathrm{RT} ; \mathrm{B}(1): \mathrm{H}_{2} \mathrm{O}, \mathrm{RT} ; \mathrm{B}(2)$ :

$\mathrm{NH}_{3} \cdot \mathrm{H}_{2} \mathrm{O}, \mathrm{RT}$; (C): FAM, SE (8), RhR-X, SE (9), ROX, SE (10), AF647, SE (11), 800CW,

$\mathrm{SE}$ (12), or Sulfo-Cy5, SE (13), $\mathrm{NaHCO}_{3} / \mathrm{DMF}$, pH 8.3-9.0, RT, in darkness.

Bioconjug Chem. Author manuscript; available in PMC 2016 November 21 
Sun et al.<smiles>O=P(O)(O)C(O)(Cc1cccnc1)P(=O)(O)O</smiles>

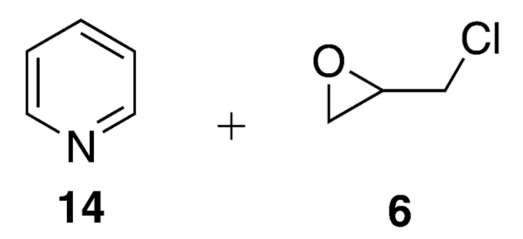<smiles>c1ccncc1</smiles>

14

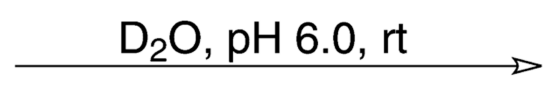

Page 25<smiles></smiles><smiles>OC(CCl)C[n+]1ccccc1</smiles>
$15 a^{C l}$

MeCN, rt

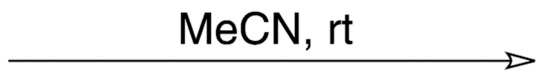<smiles>c1cc[n+](CC2CO2)cc1</smiles>

15b

Scheme 2. Reaction of Pyridine with Epichlorohydrin (6) 
Table 1

Spectroscopic Properties of Fluorescent Bisphosphonate Probes

\begin{tabular}{|c|c|c|c|}
\hline probes & $\begin{array}{l}\text { maximum absorption } \\
\text { wavelength } b \\
\left(\lambda_{\max }(\mathbf{a b s}), \mathrm{nm}\right)\end{array}$ & $\begin{array}{c}\text { maximum emission } \\
\text { wavelength }^{b} \\
\left(\lambda_{\max }(\mathrm{em}), \mathrm{nm}\right)\end{array}$ & $\begin{array}{l}\text { extinction coefficient } c, d \\
\left(\mathbf{M}^{-1} \mathrm{~cm}^{-1}\right)\end{array}$ \\
\hline 5(6)-FAM-RIS $(\mathbf{7 a 1})^{a}$ & 493 & 518 & $73,000(\mathrm{pH} 7.2)$ \\
\hline 5-FAM-RIS $(\mathbf{7} \mathbf{a} 2)^{a}$ & 493 & 521 & $73,000(\mathrm{pH} 7.2)$ \\
\hline 6-FAM-RIS $(\mathbf{7 a 3})^{a}$ & 493 & 517 & $73,000(\mathrm{pH} 7.2)$ \\
\hline 5(6)-RhR-RIS (7a4) & 567.5 & 589 & $114,850(\mathrm{pH} 7.5)$ \\
\hline 5(6)-ROX-RIS (7a5) & 580 & 606 & $72,000(\mathrm{pH} 8.0)$ \\
\hline AF647-RIS (7a6) & 648 & 666 & $240,000(\mathrm{pH} \mathrm{7.0)}$ \\
\hline 5(6)-FAM-RISPC (5(6)-FAM-3-PEHPC, 7b1 $)^{a}$ & 493 & 518 & $73,000(\mathrm{pH} 7.2)$ \\
\hline 5(6)-RhR-RISPC (5(6)-RhR-3-PEHPC, 7b2) & 568 & 589 & $114,850(\mathrm{pH} 7.5)$ \\
\hline 5(6)-ROX-RISPC (5(6)-ROX-3-PEHPC, 7b3) & 579 & 606 & $72,000(\mathrm{pH} 8.0)$ \\
\hline AF647-RISPC (AF647-3-PEHPC, 7b4) & 648 & 666 & $240,000(\mathrm{pH} \mathrm{7.0)}$ \\
\hline 5(6)-FAM-dRIS $(7 \mathbf{c 1})^{a}$ & 493 & 518 & $73,000(\mathrm{pH} 7.2)$ \\
\hline 5(6)-RhR-dRIS (7c2) & 567.5 & 589 & $114,850(\mathrm{pH} 7.5)$ \\
\hline 5-FAM-ZOL (7d1) & 493 & 521 & $73,000(\mathrm{pH} 7.2)$ \\
\hline 6-FAM-ZOL (7d2) & 493 & 516 & $73,000(\mathrm{pH} 7.2)$ \\
\hline AF647-ZOL (7d3) & 648.5 & 666 & $240,000(\mathrm{pH} \mathrm{7.0)}$ \\
\hline 800CW-ZOL (7d4) & 774 & 789 & $240,000(\mathrm{pH} \mathrm{7.0)}$ \\
\hline Sulfo-Cy5-ZOL (7d5) & 644 & 663 & 271,000 (1× PBS, $\mathrm{pH} 7.4)$ \\
\hline 5-FAM-MIN (7e1) & 493 & 522 & $73,000(\mathrm{pH} 7.2)$ \\
\hline 6-FAM-MIN (7e2) & 493 & 518 & $73,000(\mathrm{pH} 7.2)$ \\
\hline 5-FAM-MINPC (5-FAM-3-IPEHPC, 7f1) & 493 & 522 & $73,000(\mathrm{pH} 7.2)$ \\
\hline 6-FAM-MINPC (6-FAM-3-IPEHPC, 7f2) & 493 & 517 & $73,000(\mathrm{pH} 7.2)$ \\
\hline
\end{tabular}

${ }^{a}$ Previously reported. ${ }^{27}$

$b_{\text {There is }} \pm 1 \mathrm{~nm}$ error in $\lambda \lambda_{\max }(\mathrm{abs})$ and $\lambda_{\max }(\mathrm{em})$.

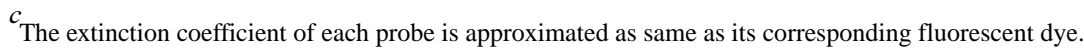

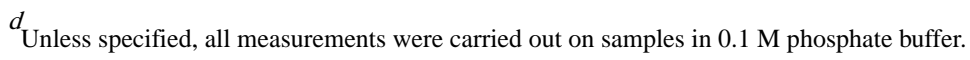

